


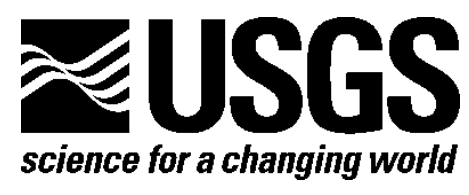

\section{Benthic Habitat Map of U.S. Coral Reef Task Force Faga'alu Bay Priority Study Area, Tutuila, American Samoa}

By Susan A. Cochran, Ann E. Gibbs, Nicole L. D'Antonio, and Curt D. Storlazzi

Open-File Report 2016-1077 


\section{U.S. Department of the Interior \\ SALLY JEWELL, Secretary}

\section{U.S. Geological Survey \\ Suzette M. Kimball, Director}

U.S. Geological Survey, Reston, Virginia: 2016

For more information on the USGS—-the Federal source for science about the Earth,

its natural and living resources, natural hazards, and the environment-visit

http://www.usgs.gov/ or call 1-888-ASK-USGS (1-888-275-8747).

For an overview of USGS information products, including maps, imagery, and publications, visit http://store.usgs.gov.

To order this and other USGS information products, visit http://store.usgs.gov/.

Any use of trade, firm, or product names is for descriptive purposes only and does not imply endorsement by the U.S. Government.

Although this information product, for the most part, is in the public domain, it also may contain copyrighted materials as noted in the text. Permission to reproduce copyrighted items must be secured from the copyright owner.

Suggested citation:

Cochran, S.A., Gibbs, A.E., D’Antonio, N.L., and Storlazzi, C.D., 2016, Benthic habitat map of U.S. Coral Reef Task Force Faga'alu Bay priority study area, Tutuila, American Samoa: U.S. Geological Survey Open-File Report 2016-1077, 32 p., http://dx.doi.org/10.3133/ofr20161077. 


\section{Contents}

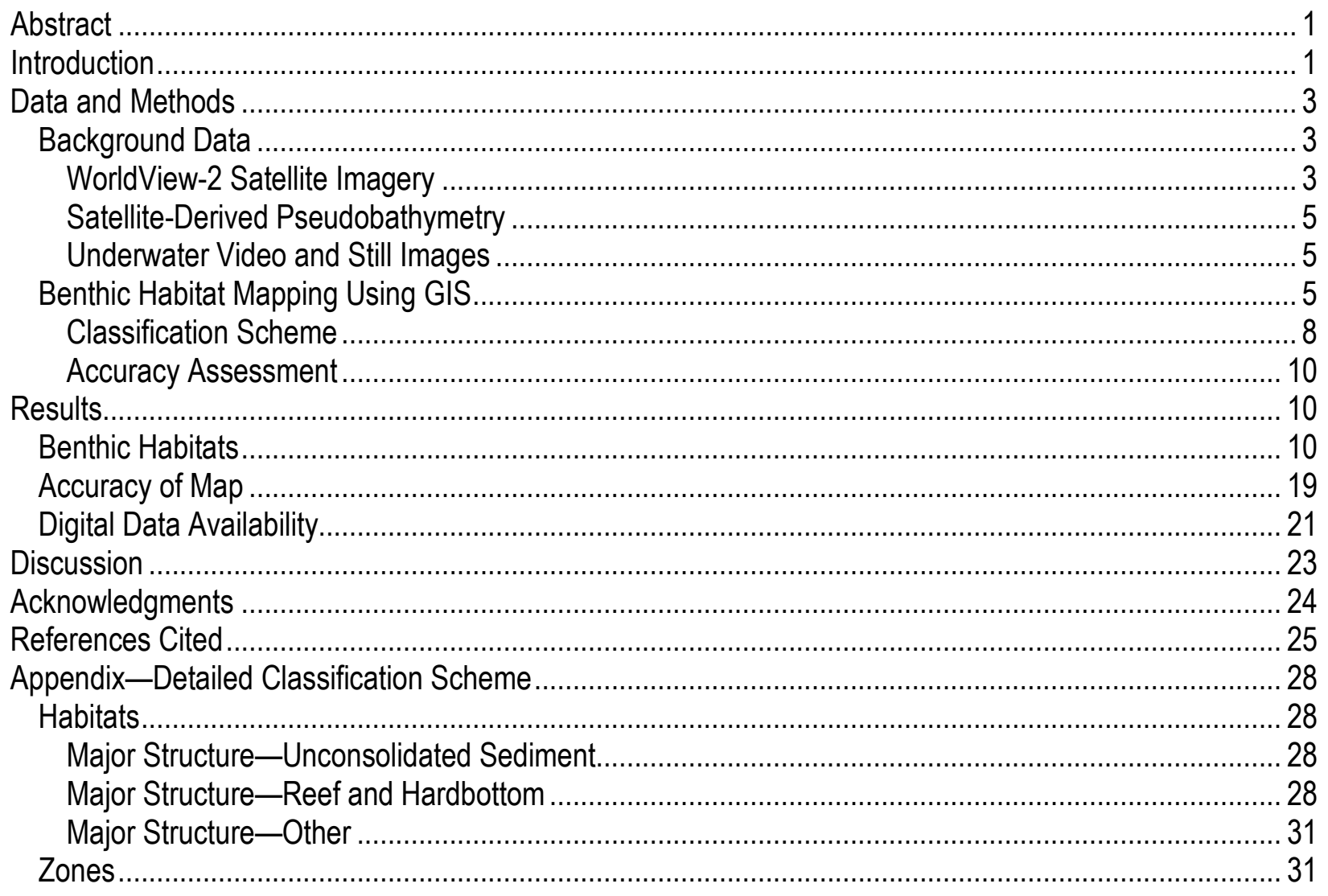

\section{Figures}

1. Map of Tutuila Island, American Samoa, showing location of U.S. Coral Reef Task Force Watershed Partnership Initiative Faga'alu Bay priority study area. Red box shows extent of area mapped in this report

2. Flowchart showing methodology used to create benthic habitat map in this report ........................ 4

3. Map of modified, satellite-derived pseudobathymetry overlaid on DigitalGlobe ${ }^{\text {TM }}$ WorldView-2 satellite imagery from November 4, 2013, in U.S. Coral Reef Task Force Watershed Partnership Initiative Faga'alu Bay priority study area, Tutuila, American Samoa

4. Map showing locations of towed-camera video transects used for interpretation of benthic habitats in U.S. Coral Reef Task Force Watershed Partnership Initiative Faga'alu Bay priority study area, overlaid on DigitalGlobe ${ }^{\text {Th }}$ WordView-2 satellite imagery from November 4, 2013, Tutuila, American

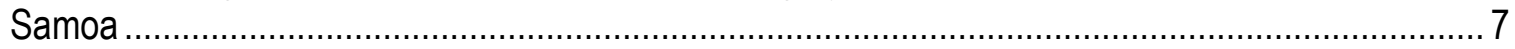

5. Schematic diagram showing generalized cross-shelf coral-reef zonation..................................... 9

6. Benthic habitat map of U.S. Coral Reef Task Force Watershed Partnership Initiative Faga'alu Bay priority study area overlaid on DigitalGlobe ${ }^{\mathrm{TM}}$ WordView-2 satellite imagery from November 4 , 2013, Tutuila, American Samoa ......

7. Charts of relative abundance of major and dominant structure/substrates, major biologic coverage on available reef and hardbottom, and percentage coral cover on available reef and hardbottom in study area 
8. Map showing dominant structures (substrates) in U.S. Coral Reef Task Force Watershed Partnership Initiative Faga'alu Bay priority study area overlaid on DigitalGlobe ${ }^{\text {Tw }}$ WordView-2 satellite imagery from November 4, 2013, Tutuila, American Samoa .....

9. Map showing distribution of cover greater than 10 percent in U.S. Coral Reef Task Force Watershed Partnership Initiative Faga'alu Bay priority study area overlaid on DigitalGlobe ${ }^{\text {TM }}$ WordView-2 satellite imagery from November 4, 2013, Tutuila, American Samoa.

10. Bar graph showing percentage of coral on available hardbottom by depth

11. Map showing geomorphic zones in U.S. Coral Reef Task Force Watershed Partnership Initiative Faga'alu Bay priority study area overlaid on DigitalGlobe ${ }^{T M}$ WordView-2 satellite imagery from November 4, 2013, Tutuila, American Samoa

12. Diagram illustrating problem of scale between minimum mapping unit (MMU) and still images used for accuracy assessment

A-1. Photograph showing an example of sand with 10-<50 percent macroalgae (Faga'alu Bay) .......... 28

A-2. Photograph showing an example of aggregate reef with $50-<90$ percent coral (Faga'alu Bay) ..... 29

A-3. Photograph showing an example of aggregated patch reef covered with $50-<90$ percent coral (Faga'alu Bay)

A-4. Photograph showing an example of scattered coral/rock with 10-<50 percent coralline algae (Faga'alu Bay)

A-5. Photograph showing an example of volcanic pavement with $50-<90$ percent turf algae (Faga'alu

Bay)

A-6. Photograph showing an example of substrate with $>50$ percent rocks/boulders, with $10-<50$ percent coral cover (Faga'alu Bay) ................................................................................ 31

A-7. Photograph showing an example of reef rubble with 10-<50 percent macroalgae (Faga'alu Bay) 31

\section{Tables}

1. Major structure (substrate) types with dominant structure subdivisions ....................................... 8

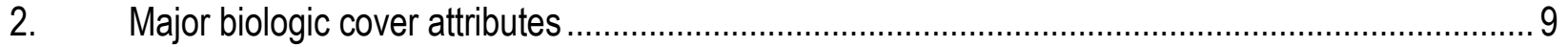

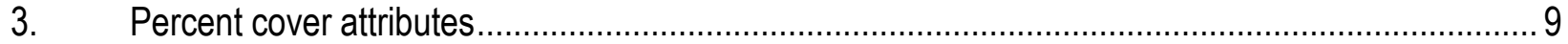

4. Geomorphic zones of coral reef ecosystems .................................................................... 10

5. Breakdown of area mapped for each dominant structure (substrate) attribute and percentage of total area mapped

6. Breakdown of area and percentage of area mapped of each major biologic cover attribute found on available reef and hardbottom substrate............................................................................ 14

7. Accuracy assessment matrix for dominant structure attributes................................................... 20

8. Accuracy assessment matrix for major biologic cover attributes ............................................... 20

9. Accuracy assessment matrix for percentage of major biologic cover attributes.............................2 21 


\section{Conversion Factors}

U.S. customary units to International System of Units

\begin{tabular}{|c|c|c|}
\hline Multiply & By & To obtain \\
\hline \multicolumn{3}{|c|}{ Length } \\
\hline foot $(\mathrm{ft})$ & 0.3048 & meter $(\mathrm{m})$ \\
\hline \multicolumn{3}{|c|}{ Area } \\
\hline acre & 4,047 & square meter $\left(\mathrm{m}^{2}\right)$ \\
\hline acre & 0.4047 & hectare (ha) \\
\hline acre & 0.4047 & square hectometer $\left(\mathrm{hm}^{2}\right)$ \\
\hline acre & 0.004047 & square kilometer $\left(\mathrm{km}^{2}\right)$ \\
\hline
\end{tabular}

International System of Units to U.S. customary units

\begin{tabular}{lcll}
\hline & Multiply & & Bo obtain \\
\hline & Length & & \\
\hline meter $(\mathrm{m})$ & 3.281 & foot $(\mathrm{ft})$ \\
meter $(\mathrm{m})$ & 1.094 & yard $(\mathrm{yd})$ & \\
\hline & Area & \\
\hline square meter $\left(\mathrm{m}^{2}\right)$ & 0.0002471 & acre \\
square kilometer $\left(\mathrm{km}^{2}\right)$ & 247.1 & acre \\
square meter $\left(\mathrm{m}^{2}\right)$ & 10.76 & square foot $\left(\mathrm{ft}^{2}\right)$ \\
square kilometer $\left(\mathrm{km}^{2}\right)$ & 0.3861 & square mile $\left(\mathrm{mi}^{2}\right)$ \\
\hline
\end{tabular}

\section{Datum}

Horizontal coordinate information is referenced to the World Geodetic System of 1984 (WGS84).

\section{Abbreviations and Acronyms}

CCA

Esri

EV-WHS

GIS

GPS

MMU

NOAA

PAEK

PIBHMC

SOEST

USCRTF

USGS crustose coralline algae

Environmental Systems Research Institute, Inc.

EnhancedView Web Hosting Service

Geographic Information System

global positioning system

minimum mapping unit

National Oceanic and Atmospheric Administration

polynomial approximation with exponential kernel

Pacific Islands Benthic Habitat Mapping Center

School of Ocean and Earth Science and Technology

U.S. Coral Reef Task Force

U.S. Geological Survey 



\title{
Benthic Habitat Map of U.S. Coral Reef Task Force Faga'alu Bay priority study area, Tutuila, American Samoa
}

\author{
By Susan A. Cochran, Ann E. Gibbs, Nicole L. D’Antonio, and Curt D. Storlazzi
}

\begin{abstract}
The coral reef in Faga'alu Bay, Tutuila, American Samoa, has suffered numerous natural and anthropogenic stresses. Areas once dominated by live coral are now mostly rubble surfaces covered with turf or macroalgae. In an effort to improve the health and resilience of the coral reef system, the U.S. Coral Reef Task Force selected Faga'alu Bay as a priority study area. To support these efforts, the U.S. Geological Survey mapped nearly $1 \mathrm{~km}^{2}$ of seafloor to depths of about $60 \mathrm{~m}$. Unconsolidated sediment (predominantly sand) constitutes slightly greater than 50 percent of the seafloor in the mapped area; reef and other hardbottom potentially available for coral recruitment constitute nearly 50 percent of the mapped area. Of this potentially available hardbottom, only slightly greater than 37 percent is covered with at least 10 percent coral, which is fairly evenly distributed between the reef flat, fore reef, and offshore bank/shelf.
\end{abstract}

\section{Introduction}

Faga'alu Bay is located on the west shore of Pago Pago Harbor, in central Tutuila Island, American Samoa. This small (about $1 \mathrm{~km}^{2}$ ) bay is fed by Faga'alu Stream, which drains one of the largest watersheds on Tutuila (fig. 1). The stream leads into an offshore channel, locally known as an "ava," that ranges from $50 \mathrm{~m}$ to $150 \mathrm{~m}$ wide and divides the reef flat into two distinct parts. The northern section of the reef flat ranges from $20 \mathrm{~m}$ to $80 \mathrm{~m}$ wide before either dropping off into the channel or transitioning to a fore reef and an offshore shelf. The southern section of the reef flat is much broader, ranging from $200 \mathrm{~m}$ to $500 \mathrm{~m}$. Much of the reef flat is shallow $(<1 \mathrm{~m}$ deep) and is exposed at low tide. There is an exposed volcanic rock outcrop about $125 \mathrm{~m}$ offshore near the outer edge of southern section of the reef flat. An offshore bank rises about 10 to $15 \mathrm{~m}$ above the shelf seaward of the fore reef in the center of the map area, and it measures about $200 \mathrm{~m}$ in the northeast-southwest direction and $400 \mathrm{~m}$ in the northwest-southeast direction.

Over the past four decades, the coral reefs of Tutuila have suffered from a number of natural impacts, including widespread mass bleaching (Abraham and others, 2004; Craig and others, 2005), outbreaks of the corallivorous (coral-eating) crown-of-thorns starfish (Acanthaster planci; U.S. Environmental Protection Agency, 2007; National Park Service, 2013), tropical cyclones (for example, Ofa in 1990; Val in 1992), unusually low tides (Fenner and others, 2008), and a tsunami in 2009 (Richmond and others, 2011). Any one of these disturbances, or likely a combination of multiple stressors, has reduced thickets of Acropora spp. (branching corals) on the Faga'alu reef flat to a field of rubble (Whaylen and Fenner, 2006). Anthropogenic 


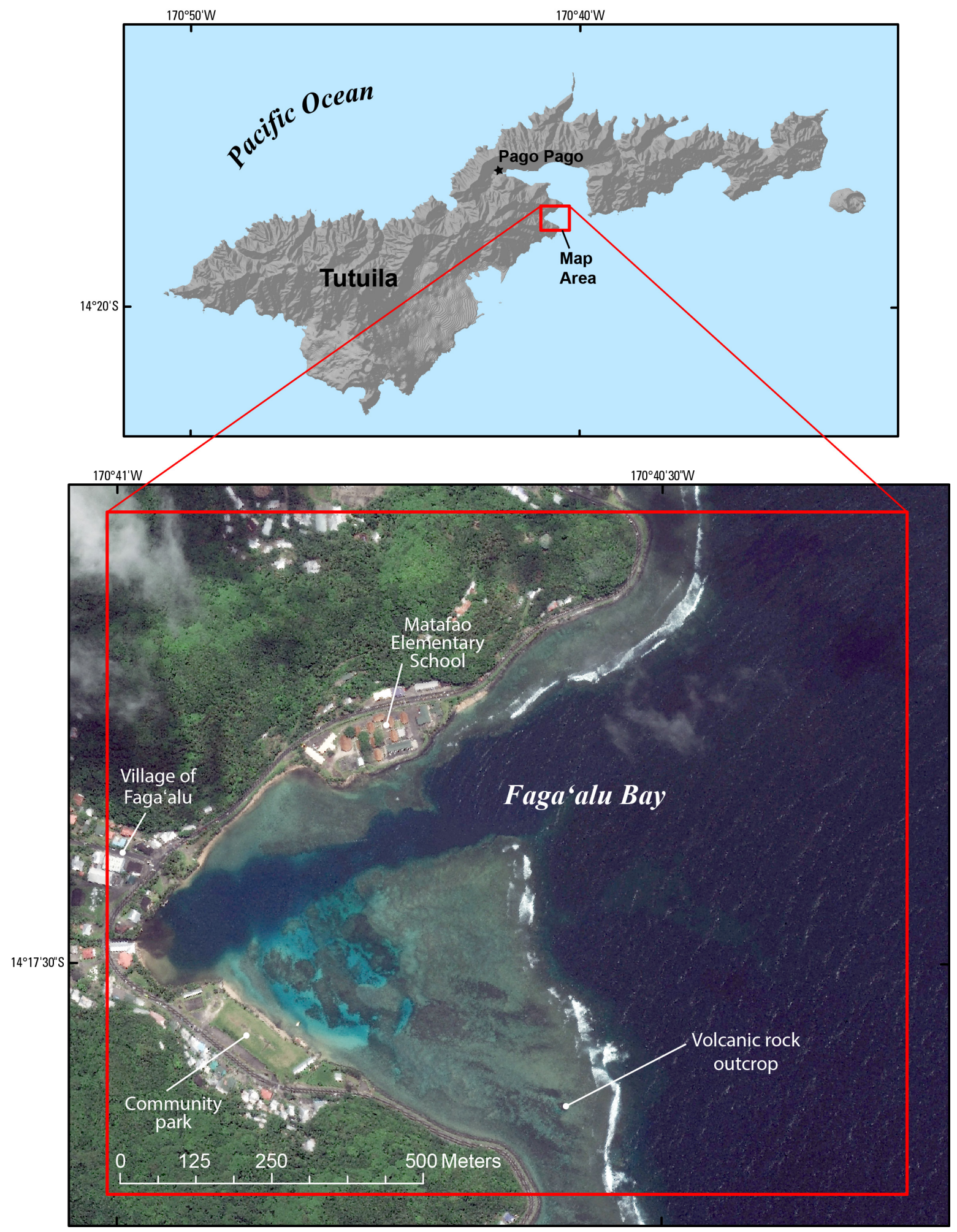

Figure 1. Map of Tutuila Island, American Samoa, showing location of U.S. Coral Reef Task Force Watershed Partnership Initiative Faga'alu Bay priority study area. Red box shows extent of area mapped in this report. DigitalGlobe ${ }^{\text {TM }}$ WorldView-2 satellite imagery from November 4, 2013. 
sedimentation and other sources of land-based pollution in the Faga' alu watershed result in high turbidity levels (Whitall and Holst, 2015), especially on the northern section of the reef flat after storm pulses (D. Fenner, written commun., 2016). High levels of sedimentation have been linked to poor reef health and can reduce the capability of a reef to recover from stresses (Rogers, 1990). On the Faga'alu reef flat, areas once covered with live coral are now under threat of the overgrowth of turf or macroalgae.

In 2012, as part of the U.S. Coral Reef Task Force (USCRTF) Watershed Partnership Initiative, Faga'alu Bay was designated as a priority area on which to focus research and restoration to help improve the health and viability of the coral reef ecosystem. To support these efforts, the U.S. Geological Survey (USGS) mapped nearly $1 \mathrm{~km}^{2}$ of seafloor using a combination of WorldView-2 satellite imagery, satellite-derived pseudobathymetry, and underwater video and photographs. Using a $100-\mathrm{m}^{2}$ minimum mapping unit (MMU), this benthic habitat map establishes current baseline conditions and will assist with monitoring and management efforts.

\section{Data and Methods}

A standard for characterization of coral-reef environments has been implemented by the National Oceanic and Atmospheric Administration (NOAA) for mapping Puerto Rico and the Virgin Islands (Kendall and others, 2001), Hawai' $i$ (Coyne and others, 2003), several U.S. Pacific Trust Territories (Analytical Laboratories of Hawaii, 2004), and the Florida Keys (Rohman and Monaco, 2005). This standard classification system for mapping describes benthic habitats on the basis of their seafloor geomorphology, geographic zonation, and biological cover.

In this study, benthic-habitat classification maps were created using the standard established by NOAA, but at a finer scale (MMU of $100 \mathrm{~m}^{2}$ compared to NOAA standards of 1 acre $\left.\left[4,046 \mathrm{~m}^{2}\right]\right)$ and with additional data sources, including DigitalGlobe ${ }^{\mathrm{TM}}$ WorldView-2 satellite imagery, satellite-derived pseudobathymetry, georeferenced underwater video, and still images captured from the underwater video. The maps were generated using ArcMap ${ }^{\mathrm{TM}}$ Geographic Information System (GIS) software by Environmental Systems Research Institute, Inc. (Esri) with a benthic habitat digitizing extension created by NOAA (National Oceanic and Atmospheric Administration, 2012), and a statistical analysis of accuracy of the resultant maps was completed. The complete methodology is shown in the flowchart in figure 2 .

\section{Background Data}

\section{WorldView-2 Satellite Imagery}

Imagery from the DigitalGlobe ${ }^{\mathrm{TM}}$ WorldView-2 satellite was used as the base layer for mapping and was obtained for research purposes through their EnhancedView Web Hosting Service (EV-WHS) at http://evwhs.digitalglobe.com. The 4-band (blue, green, red, and infrared) imagery was acquired on November 4, 2013 and has a spatial resolution of $0.60 \mathrm{~m}$ (fig. 1). The imagery has good water penetration to depths of about 5 to $10 \mathrm{~m}$ ( 15 to $30 \mathrm{ft}$; which is especially ideal for the inner reef), minimal sun glint, and less than 2 percent cloud cover over the water in the map area. 


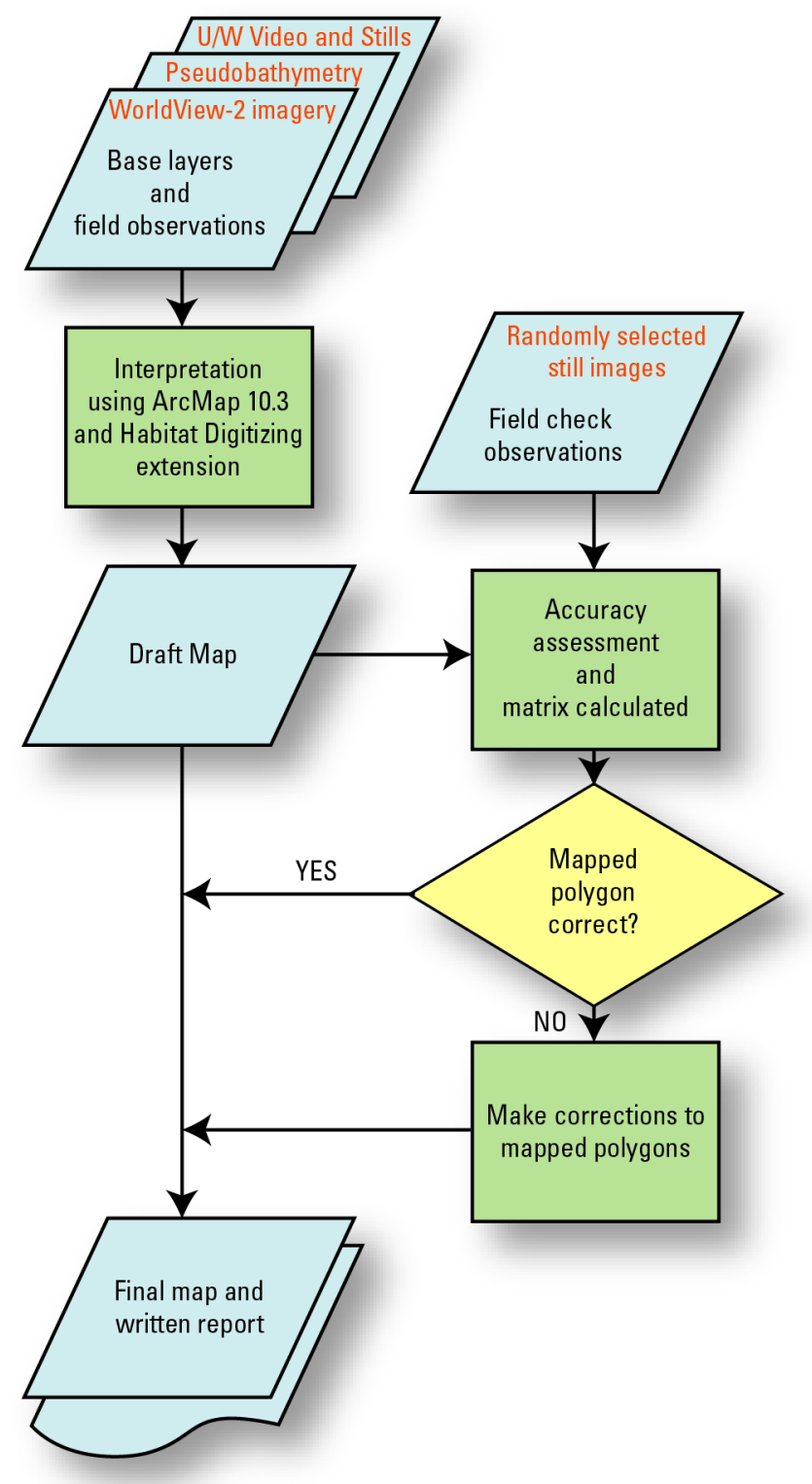

Figure 2. Flowchart showing methodology used to create benthic habitat map in this report. See text for complete description. $\mathrm{U} / \mathrm{W}$, underwater. 


\section{Satellite-Derived Pseudobathymetry}

Multibeam sonar data are available for Tutuila from about 15 to $250 \mathrm{~m}$ water depth; however, there are no multibeam data available within the shallower environment of Faga'alu Bay or offshore bank. To bridge the gap between the shoreline and the multibeam data (about 15 m water depth), Hogrefe (2008) created a pseudobathymetry map modeled from satellite-derived reflectance data (from IKONOS imagery collected in November 2001, December 2001, and February 2002), which were acquired from the Pacific Islands Benthic Habitat Mapping Center (PIBHMC) in the School of Ocean and Earth Science and Technology (SOEST) at the University of Hawai'i (available at http://www.soest.hawaii.edu/pibhmc/pibhmc_amsamoa_tutuila bathy.htm; see, also, Hogrefe and others, 2008). The modeled pseudobathymetry was modified for this study, shifting values up (shallower) by $3.3 \mathrm{~m}$ on the basis of a systematic offset between it and bathymetric data collected during the acquisition of underwater video.

Bathymetric contours were generated at 5-m intervals from the modified pseudobathymetry. The most continuous contour segments were preserved; smaller segments and isolated island polygons were excluded from the final output. Contours were smoothed using a polynomial approximation with exponential kernel (PAEK) algorithm in ArcMap and a tolerance value of $60 \mathrm{~m}$. The final bathymetric data layer overlying the WorldView-2 satellite imagery is shown in figure 3.

\section{Underwater Video and Still Images}

Underwater video footage used in the interpretation of habitats was collected along 29 transect lines using a towed camera during a USGS survey cruise in March 2014 (fig. 4). Information about the survey cruise is available at http://cmgds.marine.usgs.gov/fan_info.php? fan=2014-604-FA. More than 2,100 still images were extracted from these videos, including still frames extracted every 10 seconds along transect lines and at any obvious changes in seafloor habitat. A complete description of the methodology used to collect the underwater video footage, the techniques and software used to process the video, and the video clips themselves are available from Gibbs and D'Antonio (2016). A complete description of the methodology used to extract the still-frame images from the underwater video, benthic habitat and coral genus interpretations of the still images, and the images themselves are available from D'Antonio and Gibbs (2016).

\section{Benthic Habitat Mapping Using GIS}

Digital benthic habitat maps were created using Esri ArcGIS ${ }^{\mathrm{TM}}$ ver. 10.3 software with a habitat-digitizing extension created by NOAA (National Oceanic and Atmospheric Administration, 2012). The habitat-digitizing extension allows users to delineate habitat areas and to assign attributes to the habitat polygons based on a predetermined classification scheme using a point-and-click menu system.

Benthic habitat polygons were delineated in this study using a heads-up digitizing method. An MMU of $100 \mathrm{~m}^{2}$ was used; however, select smaller features were mapped if they carried unique habitat significance (for example, an individual coral colony $2 \mathrm{~m}$ in diameter in an otherwise uncolonized area) or if smaller fragments were created by subdividing a habitat polygon that traversed more than one geographic zone. 


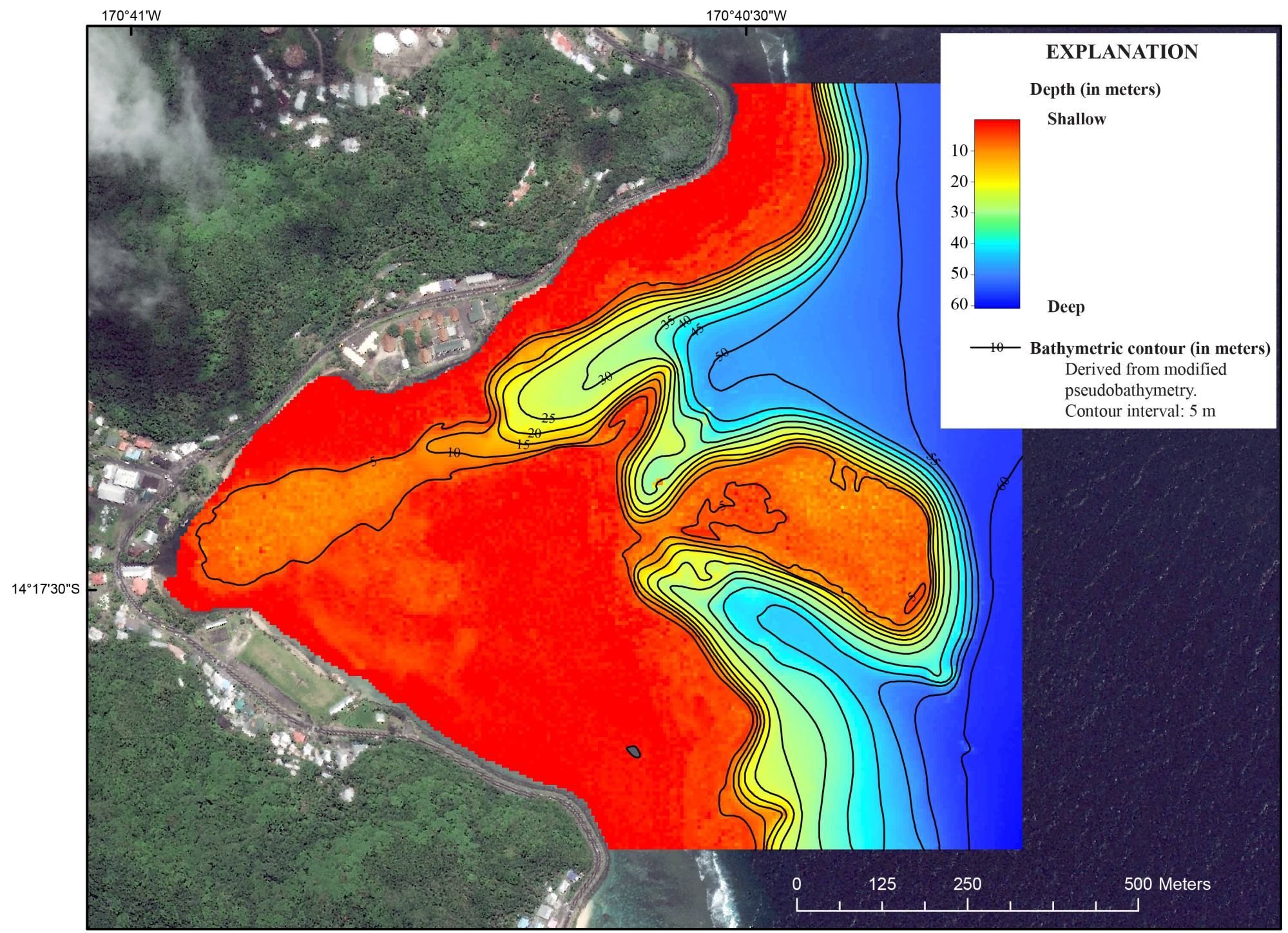

Figure 3. Map of modified, satellite-derived pseudobathymetry overlaid on DigitalGlobe ${ }^{\text {Tw }}$ WorldView-2 satellite imagery from November 4, 2013, in U.S. Coral Reef Task Force Watershed Partnership Initiative Faga'alu Bay priority study area, Tutuila, American Samoa. 


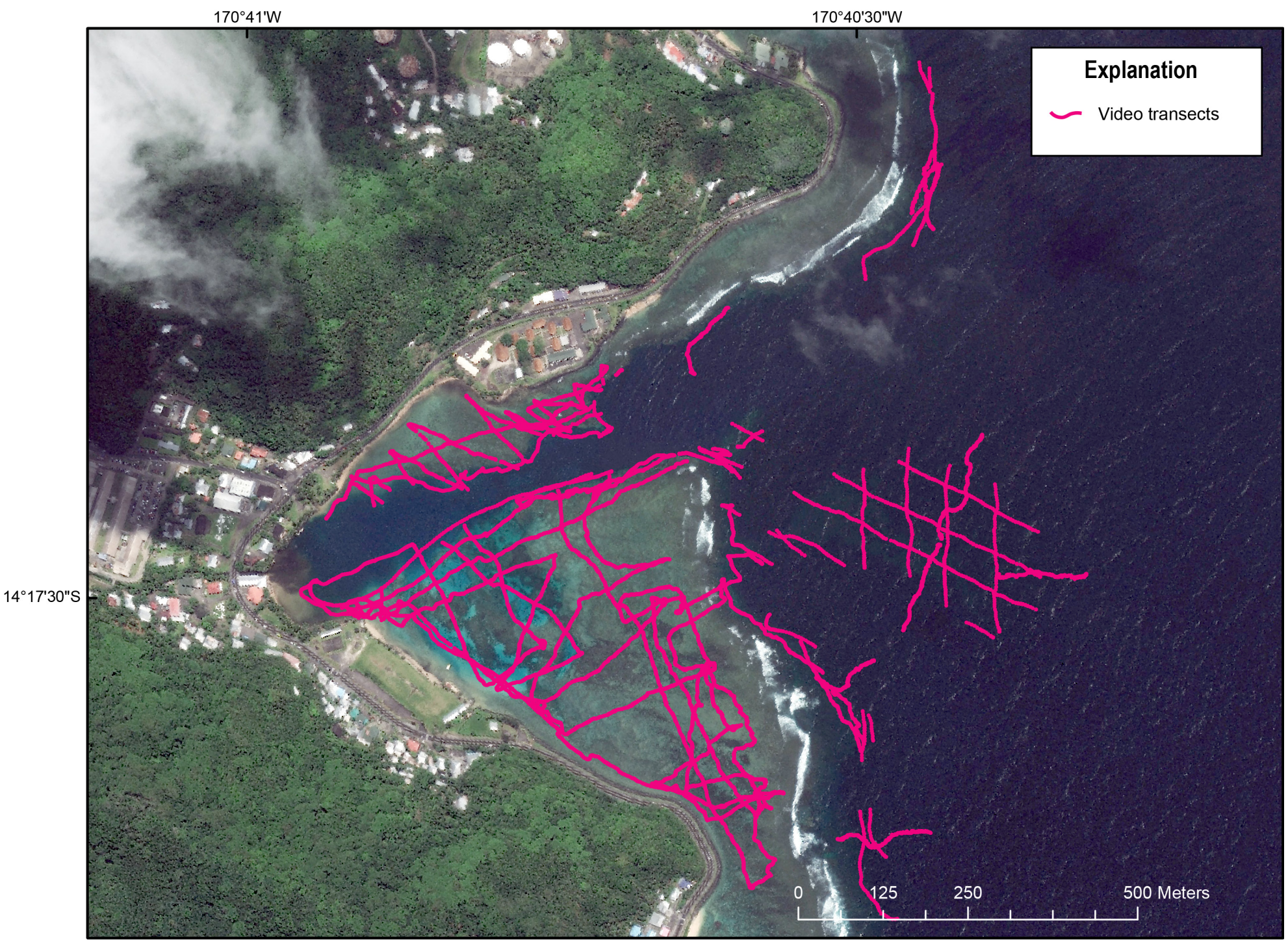

Figure 4. Map showing locations of towed-camera video transects used for interpretation of benthic habitats in U.S. Coral Reef Task Force Watershed Partnership Initiative Faga'alu Bay priority study area, overlaid on DigitalGlobe ${ }^{\mathrm{TM}}$ WordView-2 satellite imagery from November 4, 2013, Tutuila, American Samoa. 


\section{Classification Scheme}

The classification scheme used here is based on a scheme established by the NOAA biogeography benthic habitat-mapping program (Coyne and others, 2003) for the main eight Hawaiian Islands, which was subsequently modified in 2004 (Analytical Laboratories of Hawaii, 2004) for use in mapping several U.S. Pacific islands. Developed with input from coral reef scientists, managers, and local experts, the hierarchal scheme allows users to expand or collapse the level of thematic detail as necessary. The NOAA definition of benthic habitats and their classification scheme is used as a starting point to provide continuity to the coral reef scientific community.

The classification scheme uses five basic attributes to describe each polygon on the benthic habitat map: (1) the major structure or underlying substrate, (2) the dominant structure, (3) the major biologic cover found on the substrate, (4) the percentage of major biologic cover, and (5) the geographic zone indicating the location of the habitat. The structure combination, along with the overlying biologic cover, is referred to as a "habitat." At the mapping scale used $\left(100-\mathrm{m}^{2} \mathrm{MMU}\right)$, if a polygon includes two or more substrate or coverage types, the polygon is classified as the dominant type.

Four major structure (substrate) types are subdivided further into 14 dominant structures (table 1). Ten major biologic cover types also are modified by the percentage of coverage (tables $2,3)$. The classification scheme allows for any biologic cover to be found on any structure (substrate), although many combinations are unlikely (for example, coral on sand, or emergent vegetation on spur-and-groove). Less than 10 percent cover of any type is equivalent to 90-100 percent uncolonized; therefore, $0-10$ percent cover is not used. Each polygon is coded with a 4digit UNIQUEID attribute that represents the combination of the individual habitat components (major structure, dominant structure, major biologic cover, and percent cover).

Table 1. Major structure (substrate) types with dominant structure subdivisions. [Numbers in bold represent UNIQUEID identifier]

\begin{tabular}{ll}
\multicolumn{1}{c}{ Major structure } & \multicolumn{1}{c}{ Dominant structure } \\
\hline $\mathbf{1}$ Unconsolidated sediment & $\mathbf{0}$ Unknown \\
& $\mathbf{1}$ Mud \\
& $\mathbf{2}$ Sand \\
\hline $\mathbf{2}$ Reef and hardbottom & $\mathbf{0}$ Unknown \\
& $\mathbf{1}$ Aggregate reef \\
& $\mathbf{2}$ Spur-and-groove \\
& $\mathbf{3}$ Individual patch reef \\
& $\mathbf{4}$ Aggregated patch reef \\
& $\mathbf{5}$ Scattered coral/rock \\
& $\mathbf{6}$ Pavement \\
& $\mathbf{7}$ Pavement with sand channels \\
& $\mathbf{8}$ Rock/boulder (volcanic and carbonate) \\
& $\mathbf{9}$ Reef rubble \\
\hline $\mathbf{3}$ Other & $\mathbf{0}$ Unknown \\
& $\mathbf{1}$ Land \\
& $\mathbf{2}$ Artificial \\
\hline
\end{tabular}


The fifth attribute, zone, refers only to the location of a habitat community in the coral reef ecosystem and does not indicate the substrate or biologic cover type (fig. 5). Twelve zones correspond to typical reef geomorphology found in coral reef literature (table 4). Detailed descriptions of habitats and zones, including example photographs, are available in the Appendix.

Table 2. Major biologic cover attributes.

[Numbers in bold represent UNIQUEID identifier]

\section{Major biologic cover}

0 Unknown or none

1 Uncolonized

2 Macroalgae

3 Seagrass

4 Coralline algae

5 Coral

6 Turf algae

7 Emergent vegetation

8 Octocoral

Table 3. Percent cover attributes.

[Numbers in bold represent UNIQUEID identifier.]

\section{Percent cover}

0 Unknown or none

$210-<50 \%$

$350-<90 \%$

$490-100 \%$

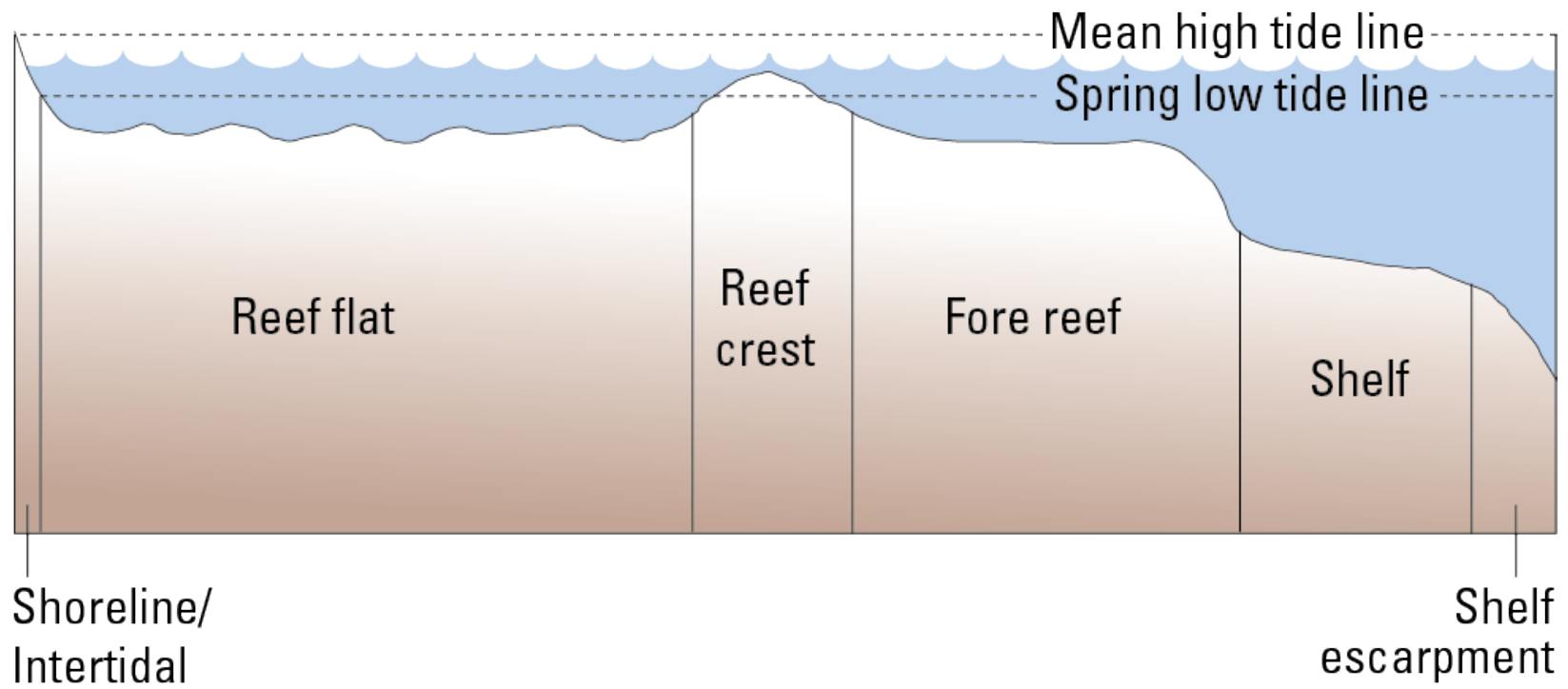

Figure 5. Schematic diagram showing generalized cross-shelf coral-reef zonation. Zones not shown: land, lagoon, channel, dredged, or wall (modified from Kendall and others, 2004). 
Table 4. Geomorphic zones of coral reef ecosystems.

Land
Shoreline/intertidal
Wall
Lagoon
Back reef (with lagoon)
Reef flat (without lagoon)
Reef crest
Fore reef
Bank/shelf
Bank/shelf escarpment
Channel
Dredged

\section{Accuracy Assessment}

The validity and usefulness of any classification or interpretation may be determined with an accuracy assessment, which compares the interpretation with what is actually found in the field. In this project, the overall accuracy of the benthic habitat map and its accuracy from the points of view of the producer and user are determined.

Overall accuracy indicates which points on the map are classified correctly according to a field check (Lillesand and Keifer, 1994). Producer accuracy indicates how well the map producer interpreted the data and classified the different cover types (that is, the number of points on the map labeled correctly). User accuracy indicates the probability that a point interpreted to be in a given class is actually represented by that class in the field (that is, which areas in the field match what is mapped).

Because no post-mapping ground-truth surveying was performed, 75 still images were randomly selected from the more than 2,100 still-image frames grabbed from the underwater video collected in March 2014 (D'Antonio and Gibbs, 2016) and held aside for the accuracy assessment prior to creating the map. These images were classified independently by a person who did not participate in the mapping efforts, which removed any bias and allowed the randomly selected images to be used to assess the accuracy of the map.

Once the accuracy assessment calculations were completed, any misidentified polygons were corrected, thereby increasing the accuracy of the final map.

\section{Results}

\section{Benthic Habitats}

Nearly 300 polygons were digitally delineated, covering nearly $1 \mathrm{~km}^{2}$ in the USCRTF Watershed Partnership Initiative Faga'alu Bay priority study area (fig. 6). Unconsolidated sediment (for example, mud and sand) makes up $0.49 \mathrm{~km}^{2}$ (slightly greater than 50 percent) of the substrate in the mapped area; the reef and hardbottom class (for example, aggregate reef, patch reefs, pavement, reef rubble, rock/boulder, and scattered coral/rock) makes up $0.48 \mathrm{~km}^{2}$ (nearly 50 percent); and other substrates (for example, artificial) make up less than $0.01 \mathrm{~km}^{2}$ $(<0.01$ percent) (fig. $7 A$ ). The areal extent and percentage of total area mapped for each of the 


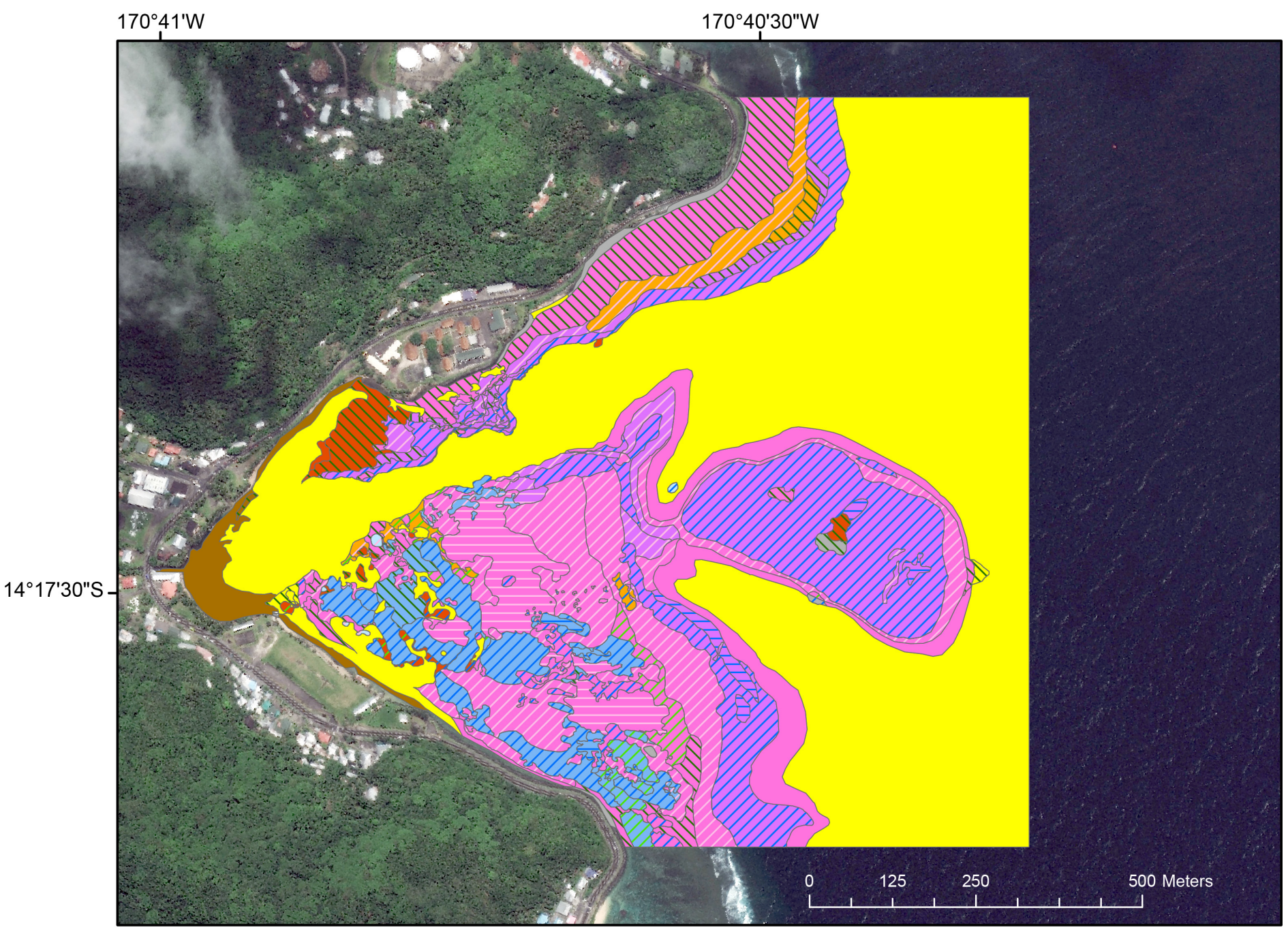

Figure 6. Benthic habitat map of U.S. Coral Reef Task Force Watershed Partnership Initiative Faga'alu Bay priority study area overlaid on DigitalGlobe ${ }^{\mathrm{TM}}$ WordView-2 satellite imagery from November 4, 2013, Tutuila, American Samoa. 


\begin{tabular}{|c|c|c|c|}
\hline \multicolumn{4}{|c|}{ Explanation } \\
\hline & Mud, Uncolonized & & Scattered coral//rock, $10-<50 \%$ Macroalgae \\
\hline & Mud, $10-<50 \%$ Turf algae & & Scattered coral/rock, $10-<50 \%$ Coral \\
\hline & Sand, Uncolonized & & Scattered coral/rock, $50-<90 \%$ Coral \\
\hline & Sand, $10-<50 \%$ Turf algae & & Scattered coral/rock, $10-<50 \%$ Turf algae \\
\hline & Aggregate reef, $10-<50 \%$ Coralline algae & & Pavement, $10-<50 \%$ Macroalgae \\
\hline & Aggregate reef, $50-<90 \%$ Coralline algae & & Pavement, $10-<50 \%$ Coralline algae \\
\hline & Aggregate reef, $10-<50 \%$ Coral & & Pavement, $10-<50 \%$ Coral \\
\hline & Aggregate reef, $50-<90 \%$ coral & & Pavement, $10-<50 \%$ Turf algae \\
\hline & Aggregate reef, $10-<50 \%$ Turf algae & & Rock/boulder, Uncolonized \\
\hline & Aggregate reef, $50-<90 \%$ Turf algae & & Rock/boulder, $10-<50 \%$ Coral \\
\hline & Individual patch reef, $10-<50 \%$ Coralline algae & & Rock/boulder, $10-<50 \%$ Turf algae \\
\hline & Individual patch reef, $10-<50 \%$ Coral & & Reef rubble, Uncolonized \\
\hline & Aggregated patch reef, $10-<50 \%$ Macroalgae & & Reef rubble, $10-<50 \%$ Macroalgae \\
\hline & Aggregated patch reef, $10-<50 \%$ Coralline algae & & Reef rubble, $10-<50 \%$ Coralline algae \\
\hline & Aggregated patch reef, $50-<90 \%$ Coralline algae & & Reef rubble, $50-<90 \%$ Coralline algae \\
\hline & Aggregated patch reef, $10-<50 \%$ Coral & & Reef rubble, $10-<50 \%$ Coral \\
\hline & Aggregated patch reef, $50-<90 \%$ Coral & & Reef rubble, $50-<90 \%$ Coral \\
\hline & Aggregated patch reef, $10-<50 \%$ Turf algae & & Reef rubble, $10-<50 \%$ Turf algae \\
\hline & Scattered coral/rock, Uncolonized & & Artificial \\
\hline
\end{tabular}

Figure 6.-Continued. 
A. Major structure/substrate Area $\left(\mathrm{km}^{2}\right)$

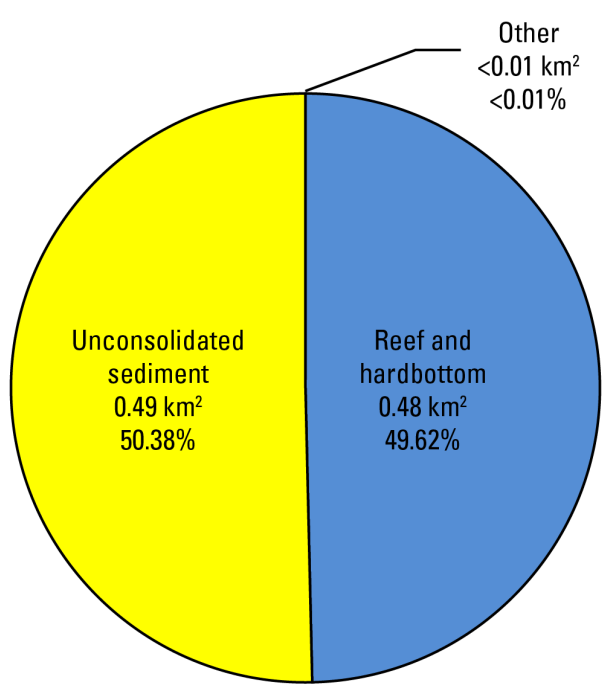

C. Major biologic cover on available reef and hardbottom Area $\left(\mathrm{km}^{2}\right)$

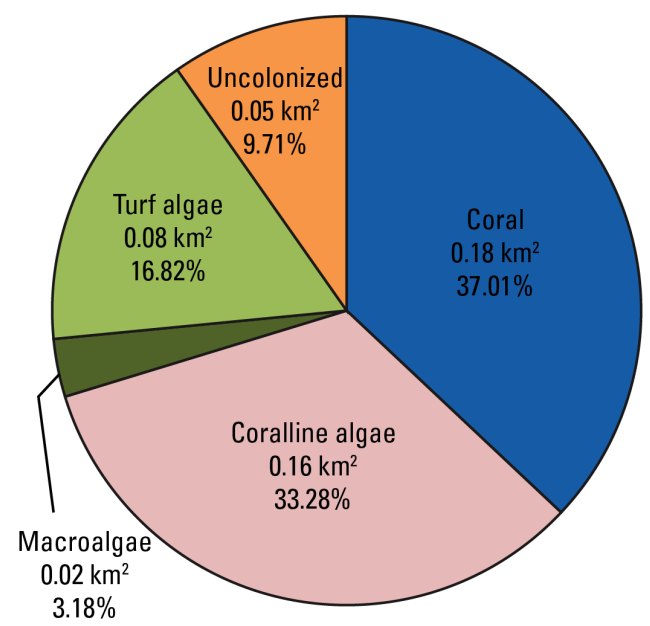

$B$. Dominant structure/substrate Area $\left(\mathrm{km}^{2}\right)$

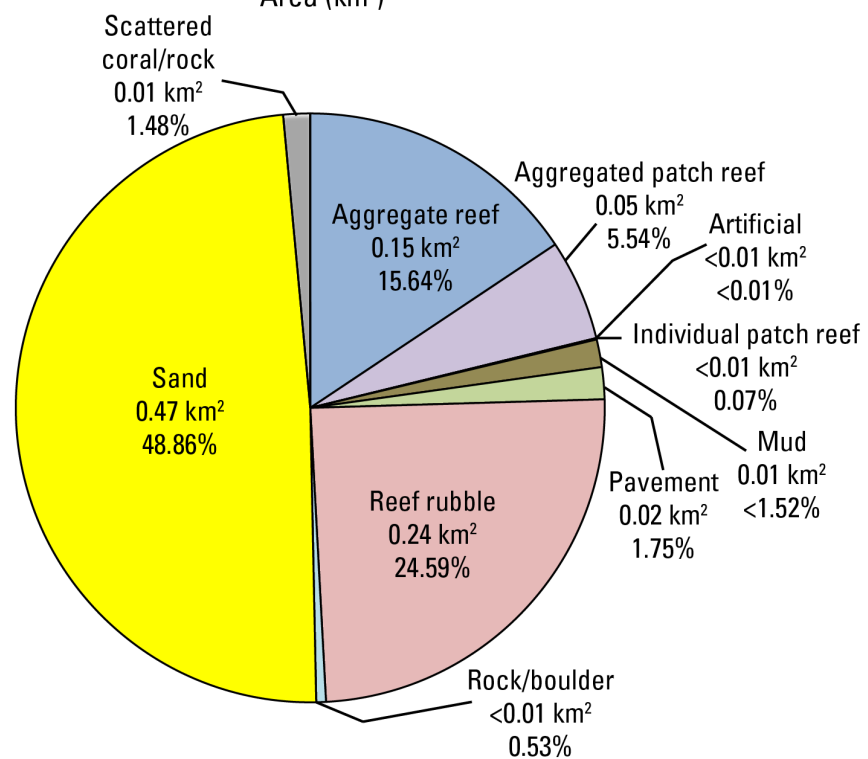

$D$. Percent coral cover on available reef and hardbottom Area $\left(\mathrm{km}^{2}\right)$

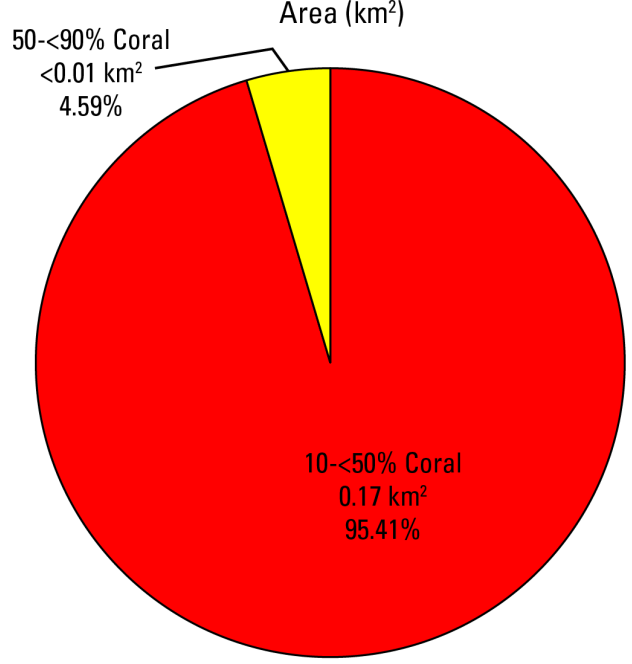

Figure 7. Charts of relative abundance of major $(A)$ and dominant $(B)$ structure/substrates, major biologic coverage on available reef and hardbottom $(C)$, and percentage coral cover on available reef and hardbottom $(D)$ in study area. Of the unconsolidated sediment in study area (just greater than 50 percent of study area) nearly all is sand $(A, B)$. Remaining nearly 50 percent of study area is reef and hardbottom available for coral habitat $(C)$. Of this available hardbottom, 37 percent is covered with minimum of 10 percent coral $(C, D)$. Most of study area is colonized with less than 50 percent live coral. 
dominant structure attributes shown on the map in figure 8 are indicated in table 5 and figure $7 B$. Of the $0.48 \mathrm{~km}^{2}$ of hardbottom potentially available for coral habitat, nearly $0.18 \mathrm{~km}^{2}(37.01$ percent) is covered with a minimum of 10 percent coral (table 6; figs. $7 C, D, 9$ ). Most coral is present in water depths between 5 and $10 \mathrm{~m}$ (fig. 10). In water depths greater than 35-40 m, no polygons were mapped as coral. Areas of coral are almost evenly distributed between the reef flat (31.91 percent), fore reef (28.47 percent), and bank/shelf zones (37.50 percent), with lesser amounts found on the reef crest and walls because of the smaller areal extent of those zones relative to the others. Scattered anthropogenic debris resulting from damage to Matafao Elementary School during the 2009 tsunami is found on the reef flat and extending down the fore reef slope just offshore of the school, however its patchy extent is too small $\left(<100 \mathrm{~m}^{2} \mathrm{MMU}\right)$ to delineate on the map.

Table 5. Breakdown of area mapped for each dominant structure (substrate) attribute and percentage of total area mapped.

\begin{tabular}{lcc}
\hline \multicolumn{1}{c}{ Dominant structure } & $\begin{array}{c}\text { Mapped area } \\
\left(\mathbf{k m}^{2}\right)\end{array}$ & $\begin{array}{c}\text { Percentage of total } \\
\text { area mapped }\end{array}$ \\
\hline Mud & 0.01 & 1.52 \\
Sand & 0.47 & 48.86 \\
Aggregate reef & 0.15 & 15.64 \\
Aggregated patch reef & 0.05 & 5.54 \\
Individual patch reef & $<0.01$ & 0.07 \\
Scattered coral/rock & 0.01 & 1.48 \\
Pavement & 0.02 & 1.75 \\
Rock/boulder & $<0.01$ & 0.53 \\
Reef rubble & 0.24 & 24.59 \\
Artificial & $<0.01$ & $<0.01$ \\
\hline
\end{tabular}

Figure 11 shows the geomorphic zones that were delineated in the mapping area. Anecdotal evidence tells of dredging of reefs around Tutuila and on the reef flat of Faga'alu Bay for construction materials, but we found it difficult to differentiate dredged areas from eroded reef flat. Except for one area of the reef flat on the south side of the channel that was dredged to provide fill for a nearby onshore community park (U.S. Army Corps of Engineers Pacific Ocean Division, 1980; Richmond, 1995), all was classified as reef flat.

Table 6. Breakdown of area and percentage of area mapped of each major biologic cover attribute found on available reef and hardbottom substrate.

\begin{tabular}{lcc}
\hline Major biologic cover & $\begin{array}{c}\text { Area on reef and } \\
\text { hardbottom }\left(\mathbf{k m}^{2}\right)\end{array}$ & $\begin{array}{c}\text { Percentage of reef and } \\
\text { hardbottom }\end{array}$ \\
\hline Coral & 0.18 & 37.01 \\
Macroalgae & 0.02 & 3.18 \\
Turf algae & 0.08 & 16.82 \\
Coralline algae & 0.16 & 33.28 \\
Uncolonized & 0.05 & 9.71 \\
\hline
\end{tabular}




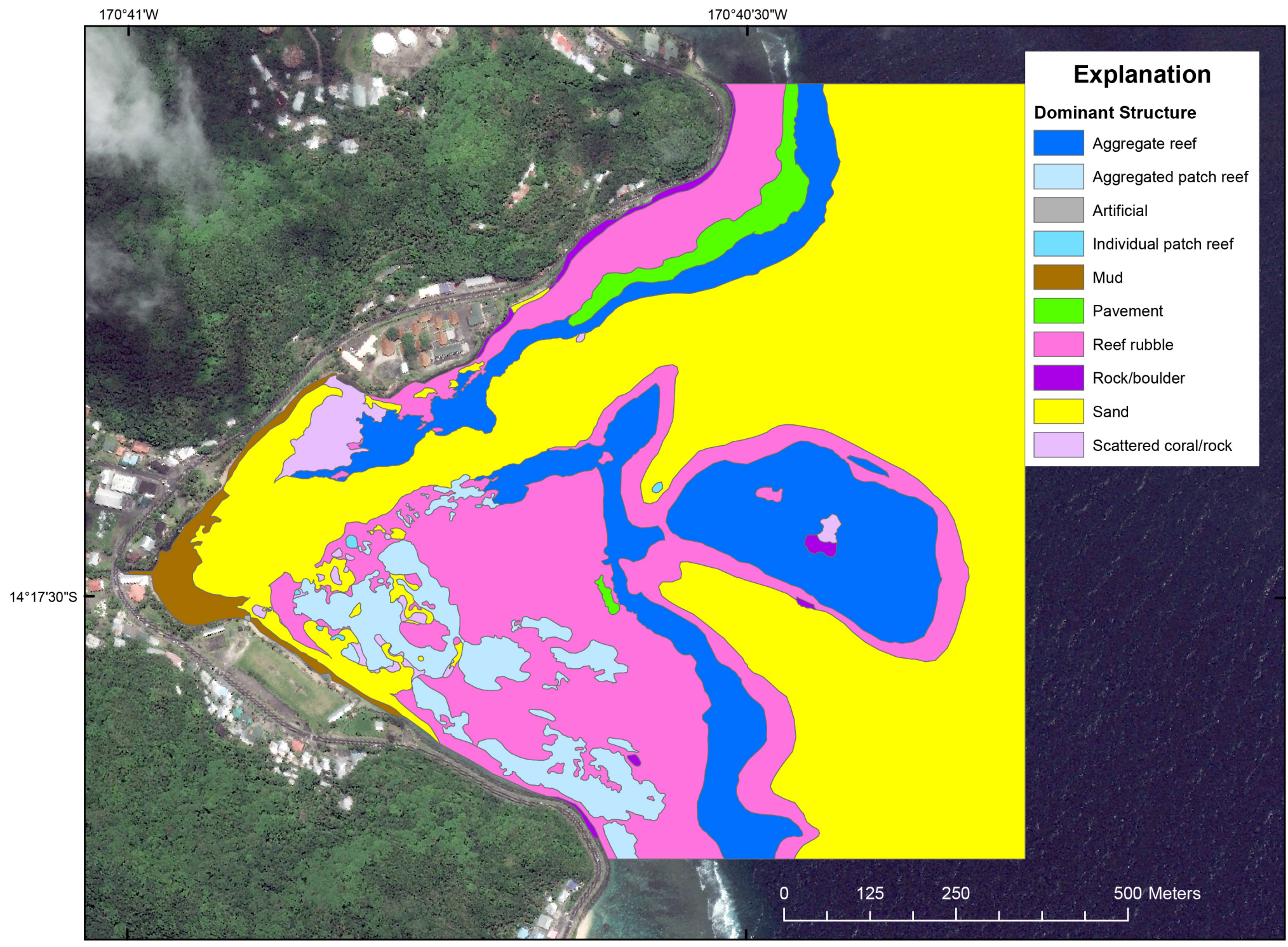

Figure 8. Map showing dominant structures (substrates) in U.S. Coral Reef Task Force Watershed Partnership Initiative Faga'alu Bay priority study area overlaid on DigitalGlobe ${ }^{\mathrm{TM}}$ WordView-2 satellite imagery from November 4, 2013, Tutuila, American Samoa. 


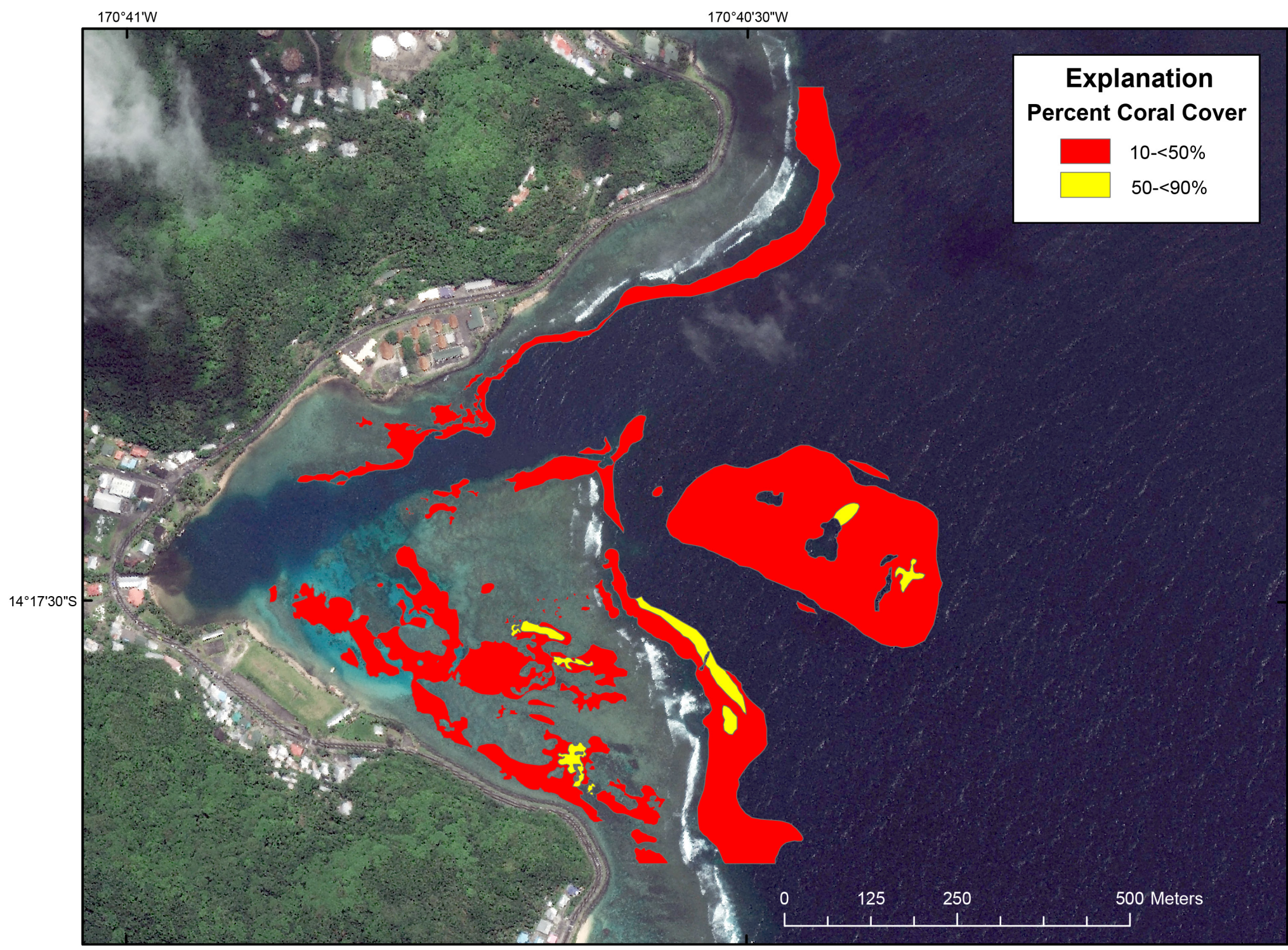

Figure 9. Map showing distribution of cover greater than 10 percent in U.S. Coral Reef Task Force Watershed Partnership Initiative Faga'alu Bay priority study area overlaid on DigitalGlobe ${ }^{\text {TW }}$ WordView-2 satellite imagery from November 4, 2013, Tutuila, American Samoa. 


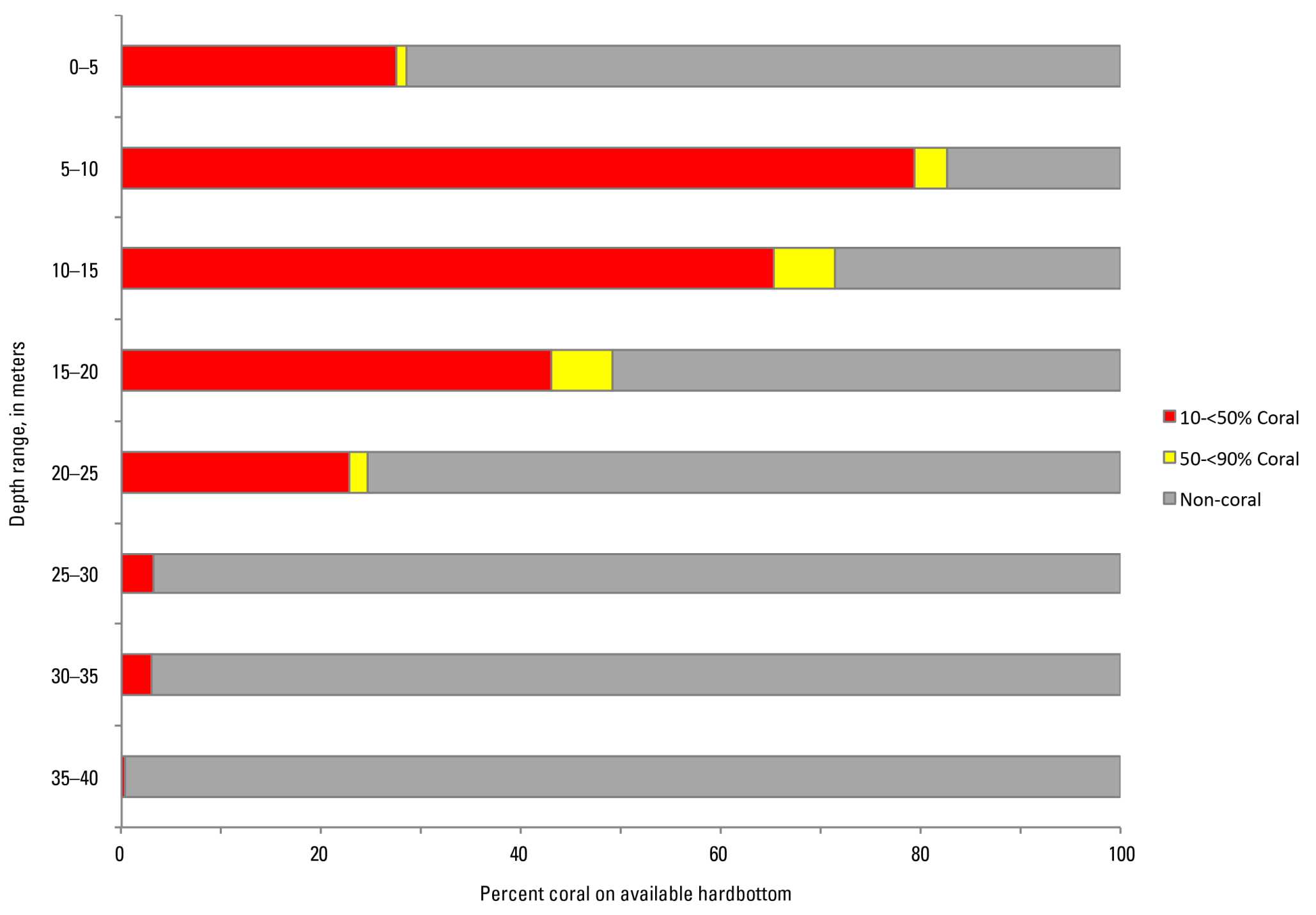

Figure 10. Bar graph showing percentage of coral on available hardbottom by depth. Coral is mostly found in water depths between 5 and $10 \mathrm{~m}$. Non-coral is uncolonized hardbottom, as well as those areas of hardbottom covered with coralline algae, turf algae, and (or) macroalgae. 


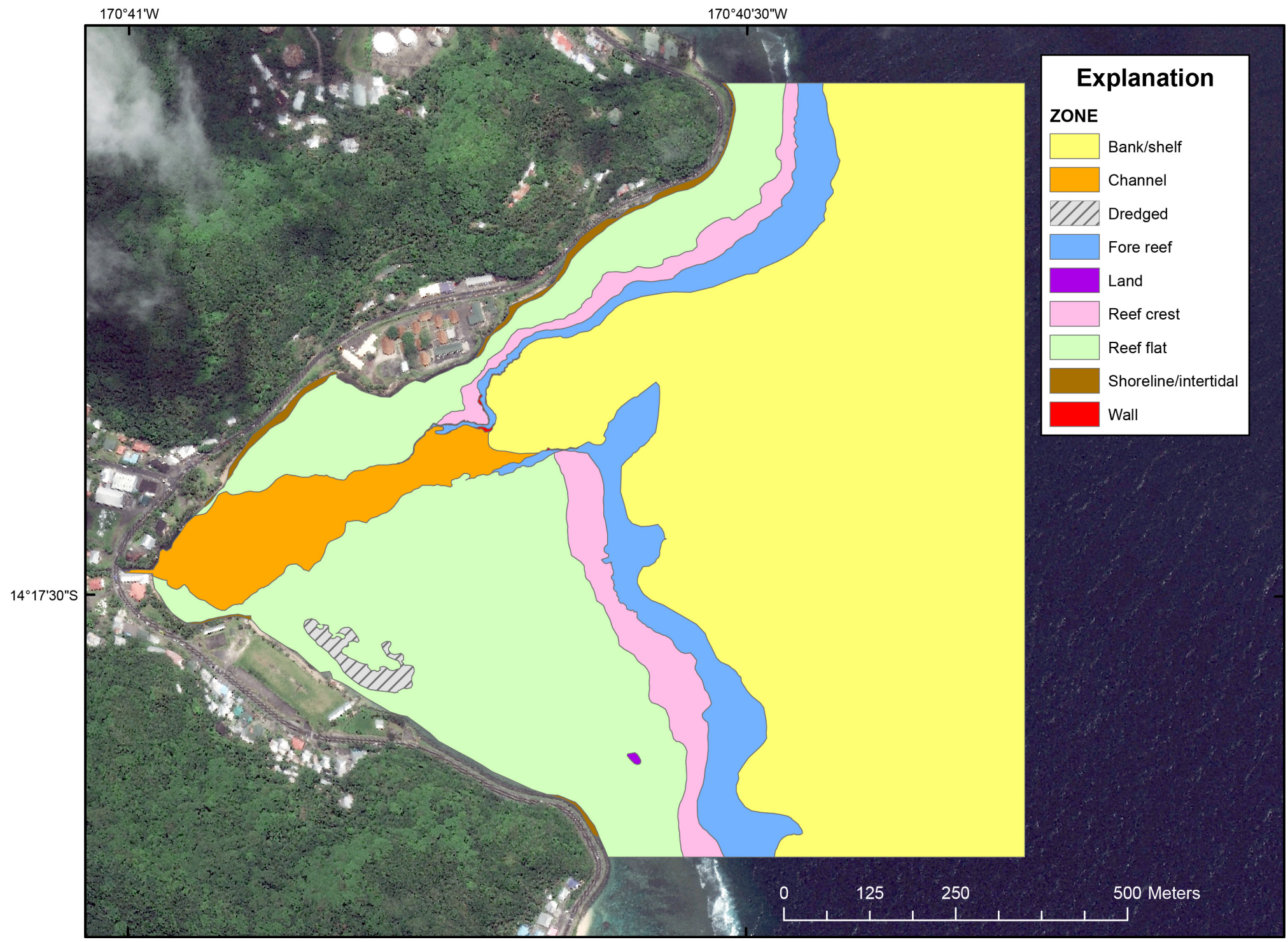

Figure 11. Map showing geomorphic zones in U.S. Coral Reef Task Force Watershed Partnership Initiative Faga'alu Bay priority study area overlaid on DigitalGlobe ${ }^{\mathrm{TM}}$ WordView-2 satellite imagery from November 4, 2013, Tutuila, American Samoa. 


\section{Accuracy of Map}

Accuracy assessments were completed for the dominant structure (table 7), major biologic cover (table 8), and percentage of major biologic cover (table 9) attributes using 75 randomly selected still-image frames from underwater video collected in March 2014. The assessments show overall accuracies of 89 percent (with a 95 percent confidence interval of \pm 7.17 percent), 68 percent (with a 95 percent confidence interval of \pm 10.6 percent), and 49 percent (with a 95 percent confidence interval of \pm 11.3 percent) for dominant structure, major biologic cover, and percentage of major biologic cover, respectively, and indicate which points on the map were classified correctly according to the field check. Producer's accuracy is an indication of how well pixels were correctly identified for each attribute (for example, for the dominant structure attribute, aggregated patch reef was identified correctly in 100 percent of instances, and reef rubble in 93 percent of instances). User's accuracy is the probability that, for a classified pixel on the map, the map user will actually find that attribute in the field (for example, for the major biologic cover attributes, coralline algae was found in the field in 71 percent of corresponding pixels, and turf algae in 64 percent). Tau coefficients $\left(T_{e}\right)$ for the accuracy assessments of the dominant structure, major biologic cover, and percentage of major biologic cover were calculated as described by Ma and Redmond (1995), and they indicate that 86 percent, 60 percent, and 43 percent more points were classified correctly in each respective attribute than would be expected solely by chance.

We found that many discrepancies between the classified polygons on the map and the classified still-image frames were a direct result of the difference in scale between the MMU and the still images used for the accuracy assessment. Whereas the map is classified based on what is found in a polygon $100 \mathrm{~m}^{2}$ or larger, the still images cover a much smaller area (typically $1 \mathrm{~m}$ or smaller, especially on the shallow reef flat). Figure 12 illustrates the problem of this difference in scale.

The difference in layback position of the towed camera versus the global positioning system (GPS) receiver on the boat led to a couple of the randomly chosen still images from the underwater video being located near the edge of a transition zone between two polygons. In those instances, the mapped polygons were classified based on the WorldView-2 base-layer image mosaic rather than the still images.

Lastly, the polygon in which a still image was located might be classified based on the surroundings using an assumption of continuity in an area, but the still image might be classified as "unknown" because of the scale of focus.

After accuracy assessment calculations were completed, any misinterpreted polygons (not including those that were interpreted differently because of the difference listed above) were corrected using the field check data, thereby increasing the overall accuracy of the final map. 
Table 7. Accuracy assessment matrix for dominant structure attributes.

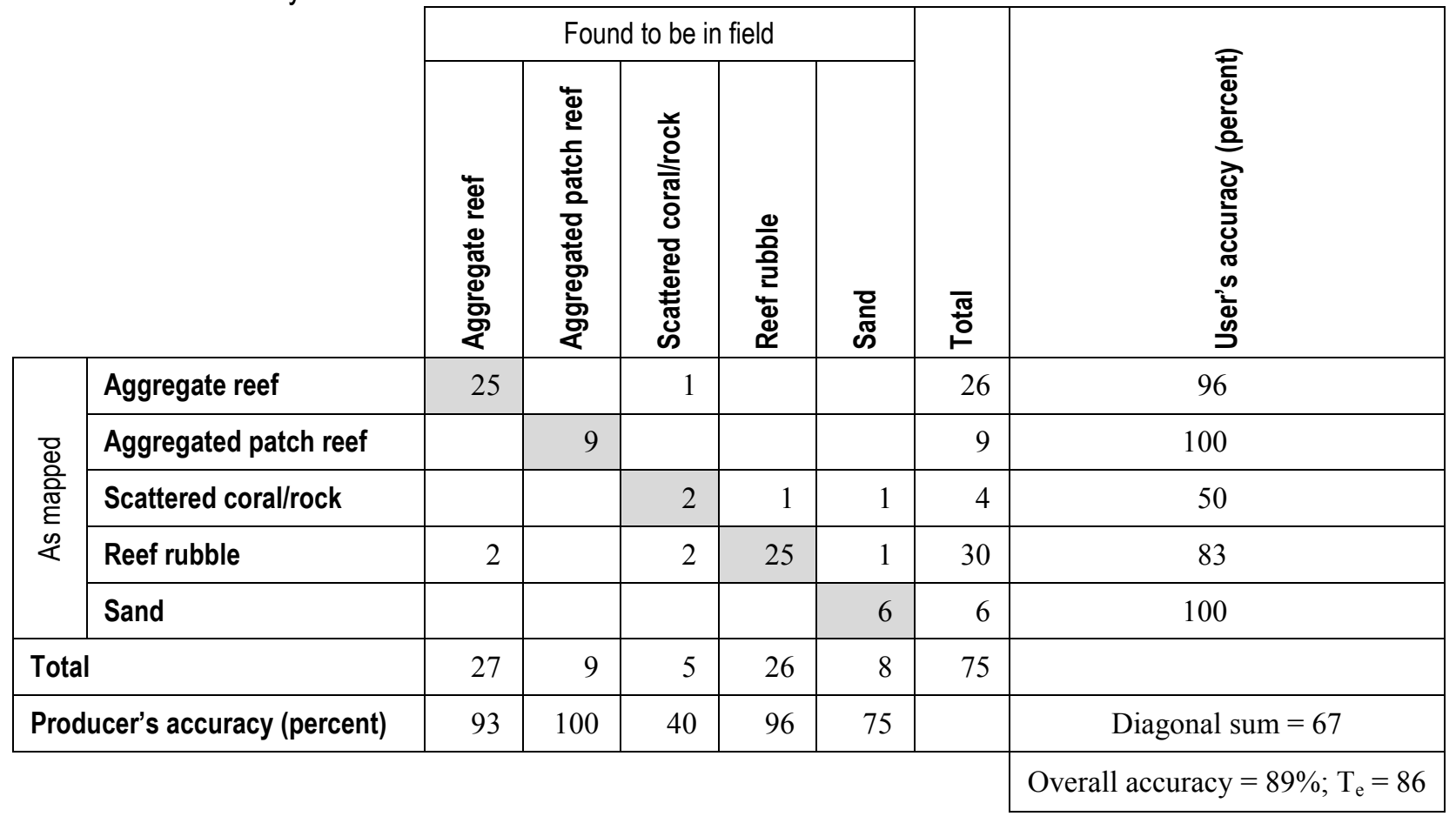

Table 8. Accuracy assessment matrix for major biologic cover attributes.

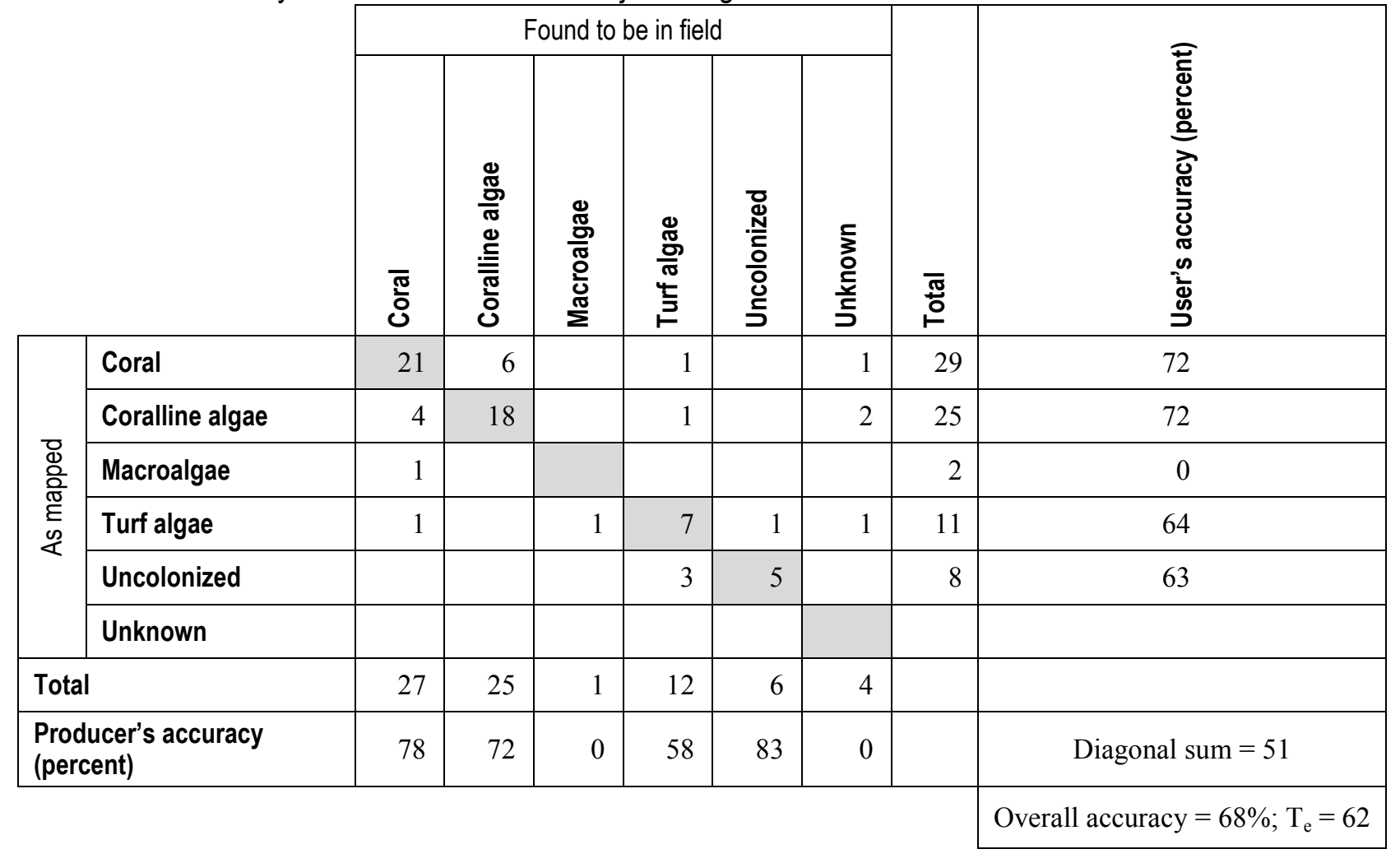


Table 9. Accuracy assessment matrix for percentage of major biologic cover attributes.

\begin{tabular}{|c|c|c|c|c|c|c|c|c|c|c|c|c|}
\hline & \multicolumn{9}{|c|}{ Found to be in field } & \multirow[b]{2}{*}{$\begin{array}{l}\bar{\pi} \\
\text { 。 } \\
\end{array}$} & \multirow[b]{2}{*}{ 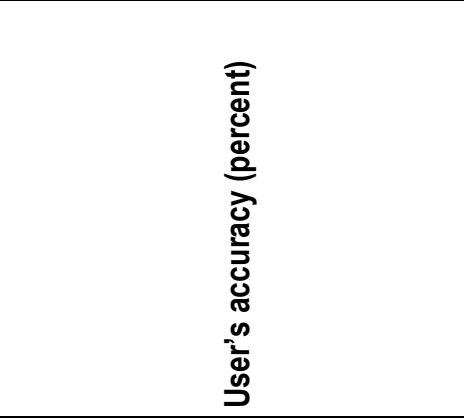 } \\
\hline & & 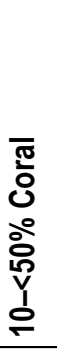 & 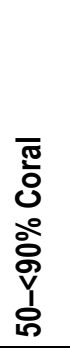 & 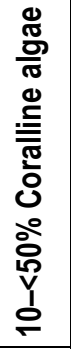 & 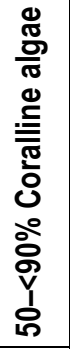 & 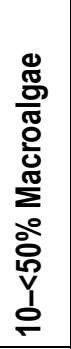 & 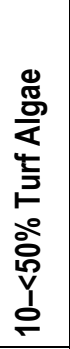 & 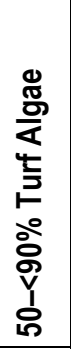 & 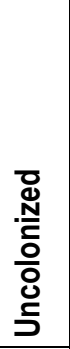 & 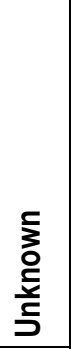 & & \\
\hline \multirow{9}{*}{$\begin{array}{l}\frac{0}{\Phi} \\
\frac{0}{2} \\
\stackrel{0}{\overline{0}} \\
\frac{0}{2} \\
\frac{0}{<}\end{array}$} & $10-<50 \%$ Coral & 13 & 4 & 3 & 3 & & 1 & & & 1 & 25 & 52 \\
\hline & $50-<90 \%$ Coral & & 4 & & & & & & & & 4 & 100 \\
\hline & $\begin{array}{l}10-<50 \% \\
\text { Coralline algae }\end{array}$ & 4 & & 6 & 7 & & 1 & & & 2 & 20 & 30 \\
\hline & $\begin{array}{l}50-<90 \% \\
\text { Coralline algae }\end{array}$ & & & 2 & 3 & & & & & & 5 & 60 \\
\hline & $\begin{array}{l}10-<50 \% \\
\text { Macroalgae }\end{array}$ & & 1 & 1 & & & & & & & 2 & 0 \\
\hline & $\begin{array}{l}10-<50 \% \\
\text { Turf algae }\end{array}$ & 1 & & & & 1 & 6 & 1 & 1 & 1 & 11 & 55 \\
\hline & $\begin{array}{l}50-<90 \% \\
\text { Turf Algae } \\
\end{array}$ & & & & & & & & & & & \\
\hline & Uncolonized & & & & & 2 & 1 & 5 & & & 8 & 63 \\
\hline & Unknown & & & & & & & & & & & \\
\hline \multicolumn{2}{|c|}{ Total } & 18 & 9 & 12 & 13 & 1 & 10 & 2 & 6 & 4 & & \\
\hline \multicolumn{2}{|c|}{$\begin{array}{l}\text { Producer's } \\
\text { accuracy (percent) }\end{array}$} & 72 & 44 & 50 & 23 & 0 & 60 & 0 & 83 & 0 & & Diagonal sum $=37$ \\
\hline & & & & & & & & & & & & Overall accuracy $=49 \% ; T_{e}=42$ \\
\hline
\end{tabular}

\section{Digital Data Availability}

The GIS shapefile for the benthic habitat map is available for digital download from the USGS at http://dx.doi.org/10.3133/ofr2016177.

Field activity information for the collection of the underwater video footage used in this report is available from the USGS at http://cmgds.marine.usgs.gov/fan_info.php?fan=2014-604FA.

Underwater video footage is available from the USGS at http://dx.doi.org/10.5066/ F70V89V6, and the associated still-images are available at http://dx.doi.org/10.5066/F7N877V1. 


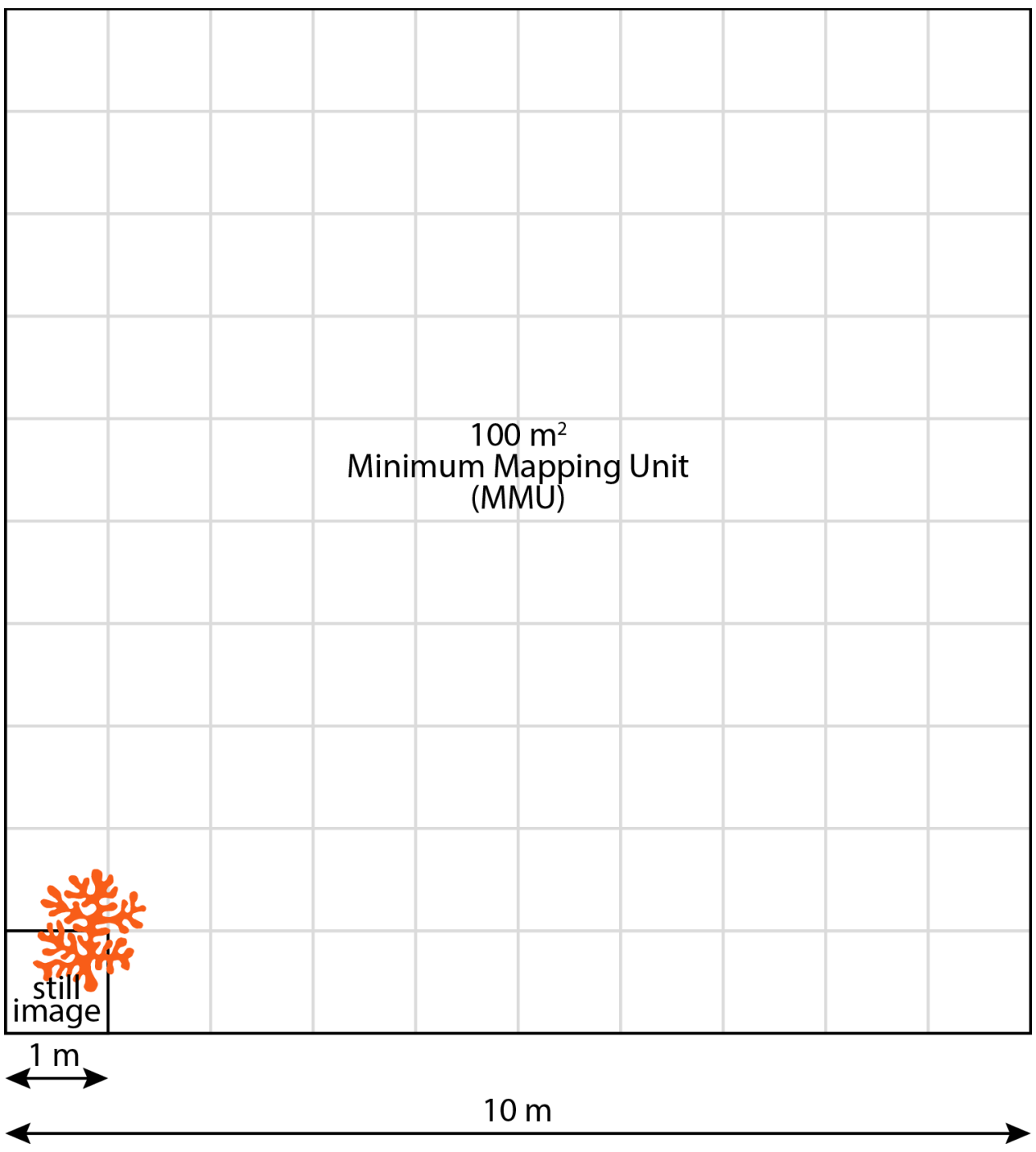

Figure 12. Diagram illustrating problem of scale between minimum mapping unit (MMU) and still images used for accuracy assessment. In example shown, discrepancy occurs when polygon is classified as "Uncolonized" (because of less than 10 percent biologic cover in MMU), but still image used for the accuracy assessment is classified as $10-<50$ percent Coral. 


\section{Discussion}

The reef flat on the north side of the channel in Faga'alu Bay is relict aggregate reef with topographical relief of about $1.5 \mathrm{~m}$ or less. The aggregate reef has started to degrade, and is very porous, with patchy erosional holes in the substrate.

The northernmost part of the reef flat on the south side of the channel is degraded. Owing to the presence of reef rubble, we infer that this area was previously a combination of aggregate reef (similar to the reef flat on the north side of the channel) and patch reefs that has been degraded. What might be pavement between and surrounding these reefs is also covered with rubble. The southernmost part of the reef flat on the south side of the channel is mostly covered with turf and macroalgae. Low coral cover (about 10 percent) is intermixed with coralline algae on reef rubble, and formerly live coral being taken over by turf algae and cyanobacteria (which is mapped as macroalgae). Even the aggregate patch reefs in the middle of the reef flat on the south side of the channel show signs of degradation, and are becoming colonized by turf algae and cyanobacteria. The presence of cyanobacteria indicates possible nutrient enrichment in this south part of the map area.

The biological cover on the reef flat, both on the north side and south side of the channel, is patchy and intermingled between coral, coralline algae, macroalgae, and turf algae. Efforts were made to delineate polygons that are representative of the conditions at the time of the satellite imagery and underwater imagery, but because the nature of these cover types (especially macroalgae and turf algae) is ephemeral and the abundance of each may change periodically or even seasonally, the boundaries of these polygons may become less accurate with time. Crustose coralline algae (CCA) can be beneficial as it encrusts and binds reef rubble, thus providing a stable substrate for coral recruitment after a major disturbance. CCA has also been shown to induce metamorphosis and settlement of coral larvae as well as increase survivorship of recruits (Morse and others, 1988; Morse and Morse, 1991; Heyward and Negri, 1999; Raimondi and Morse, 2000; Harrington and others, 2004). Many of the small corals ( $<100 \mathrm{~cm}$ in diameter) found on reef rubble on the reef flat have likely attached or settled since the 2009 tsunami, and their subsequent growth may be indicative of the coral reef ecosystem's slow recovery.

The large offshore bank seaward of the fore reef in the middle of the map area is an aggregate reef that is vertically cut with many narrow $(<1 \mathrm{~m})$ sand channels. Channels run both shore normal and parallel, so they probably do not indicate a relict spur-and-groove structure, but rather the fracture patterns of the underlying volcanic substrate. The sides of this offshore bank drop off sharply, transitioning from aggregate reef covered with coralline algae and scattered corals, to reef rubble covered with coralline algae and scattered corals, to sand.

Areas of unconsolidated sediment (mud and sand), such as the offshore shelf, channel, and pockets on the inner reef flat, are dotted with burrows, mostly from fiddler crabs (Uca sp.; U.S. Army Corps of Engineers, 1980).

The benthic habitat map was created using DigitalGlobe ${ }^{\mathrm{TM}}$ WorldView-2 satellite imagery from 2013, satellite-derived pseudobathymetry (from IKONOS imagery collected in 2001 and 2002), and underwater video footage collected in 2014, and reflects the benthic habitats found at those times. Repeat mapping in the future would be beneficial for change detection and to help determine if management priorities are being met. 


\section{Acknowledgments}

This project was funded by the USGS Pacific Coastal and Marine Geology Program Pacific Coral Reef Project as part of an effort in the United States and Pacific Island Trust Territories to better understand the effect of geologic and oceanographic processes on coral reef ecosystems. We thank Tim Clark and the staff of the National Park of American Samoa, Alex Messina (San Diego State University), and Hideyo Hattori (NOAA) for their help with boats and other logistics. This report benefited from reviews and suggestions by Joshua B. Logan and VeeAnn A. Cross (both USGS) and Douglas Fenner (Ocean Associates; formerly with the American Samoa Department of Marine and Wildlife Resources). 


\section{References Cited}

Abraham, T., Beger, M., Burdick, D., Cochrane, E., Craig, P., Didonato, G., Fenner, D., Green, A., Golbuu, Y., Gutierrez, J., Hasurmai, M., Hawkins, C., Houk, P., Idip, D., Jacobson, D., Joseph, E., Keju, T., Kuartei, J., Palik, S., Penland, L., Pinca, S., Rikim, K., Starmer, J., Trianni, M., Victor, S., and Whaylen, L. (Kelty, R. and Kuartei, J., eds.), Status of the Coral Reefs in Micronesia and American Samoa, chap 14 of Wilkinson, C., 2004, Status of coral reefs of the world-Volume 2: Australian Institute of Marine Science, p. 381-409, available at http://www.icriforum.org/sites/default/files/scr2004v2-all.pdf.

Analytical Laboratories of Hawaii, 2004, Mapping of benthic habitats for U.S. Pacific Territories-American Samoa, Guam, and The Commonwealth of the Northern Mariana Islands; Task Order II Project Completion Report: Prepared by Analytical Laboratories of Hawaii for BAE Systems Spectral Solutions under contract to NOAA, available at http://coastalscience.noaa.gov/datasets/e99/Final_BenHabAS_Guam_CNMI.pdf.

Coyne, M.S., Battista, T.A., Anderson, M., Waddell, J., Smith, W., Jokiel, P., Kendall, M.S., and Monaco, M.E., 2003, Benthic habitats of the main Hawaiian Islands: National Oceanic and Atmospheric Administration Technical Memorandum NOS NCCOS CCMA 152, available at http://products.coastalscience.noaa.gov/collections/benthic/e97hawaii/default.aspx.

Craig, P., DiDonato, G., Fenner, D., and Hawkins, C., 2005, The state of coral reef ecosystems of American Samoa, in Waddell, J. (ed.), The status of the coral reef ecosystems of the US and Pacific freely associated states: NOAA Technical Memorandum NOS NCCOS 11, NOAA/NCCOS Center for Coastal Monitoring and Assessment's Biogeography Team, Silver Spring, MD, p. 312-337, available at http://www.botany.hawaii.edu/basch/uhnpscesu/pdfs/ sam/Craig2005StateAS.pdf.

D’Antonio, N.L., and Gibbs, A.E., 2016, Still-image frame grabs and benthic habitat interpretation of underwater video footage, March 2014, Faga'alu Bay, Tutuila Island, American Samoa: U.S. Geological Survey data release, http://dx.doi.org/10.5066/F7N877V1.

Fenner, D., Speicher, M., Gulick, S., Aeby, A., Aletto, S.C., Anderson, P., Carroll, B., DiDonato, E., DiDonato, G., Farmer, V., Gove, J., Houk, P., Lundblad, E., Nadon, M., Riolo, F., Sabater, M., Schroeder, R., Smith, E., Tuitele, C., Tagarino, A., Vaitautolu, S., Vaoli, E., VargasAngel, B., and Vroom, P., 2008, The state of coral reef ecosystems of American Samoa, in Waddell, J.E., and Clarke, A.M. (eds.), The state of coral reef ecosystems of the United States and Pacific Freely Associated States: NOAA Technical Memorandum NOS NCCOS 73, p. 307-351, available at https://coastalscience.noaa.gov/research/docs/CoralReport2008.pdf.

Gibbs, A.E., and D’Antonio, N.L., 2016, Underwater video footage, March 2014, Faga'alu Bay, Tutuila Island, American Samoa: U.S. Geological Survey data release, http://dx.doi.org/ 10.5066/F70V89V6.

Harrington, L., Fabricius, K., De'Ath, G., and Negri, A., 2004, Recognition and selection of settlement substrata determine post-settlement survival in corals: Ecology, v. 85, p. 3,4283,437 .

Heyward, A.J., and Negri, A.P., 1999, Natural inducers of coral larval metamorphosis: Coral Reefs, v.18, p. 273-279.

Hogrefe, K.R., 2008, Derivation of near-shore bathymetry from multispectral satellite imagery used in a coastal terrain model for the topographic analysis of human influence on coral reefs: Corvallis, Oregon, Oregon State University, M.S. thesis, 117 p. 
Hogrefe, K.R., Wright, D.J., and Hochberg, E.J., 2008, Derivation and integration of shallowwater bathymetry-Implications for coastal terrain modeling and subsequent analyses: Marine Geodesy, v. 31, p. 299-317.

Kendall, M.S., Monaco, M.E., Buja, K.R., Christensen, J.D., Kruer, C.R., Finkbeiner, M., and Warner, R.A., 2001, Methods used to map the benthic habitats of Puerto Rico and the U.S. Virgin Islands: National Oceanic and Atmospheric Administration, 45 p., http://www2. coastalscience.noaa.gov/publications/.

Kendall, M.S., Buja, K.R., Christensen, J.D., Kruer, C.R., and Monaco, M.E., 2004, The seascape approach to coral ecosystem mapping-An integral component of understanding the habitat utilization patterns of reef fish: Bulletin of Marine Science, v. 75, no. 2, p. 225-237.

Lillesand, T.M., and Keifer, R.W., 1994, Remote sensing and image interpretation (3d ed.): New York, John Wiley and Sons, $750 \mathrm{p}$.

Ma, Z., and Redmond, R.L., 1995, Tau coefficients for accuracy assessment of classification of remote sensing data: Photogrammetric Engineering and Remote Sensing, v. 61, p. 435-439.

Morse, D.E., Hooker, N., Morse, A.N.C., and Jensen, R.A., 1988, Control of larval metamorphosis and recruitment in sympatric agariciid corals: Journal of Experimental Marine Biology and Ecolology, v. 116, p. 193-217.

Morse, D.E., and Morse, A.N.C., 1991, Enzymatic characterization of the morphogen recognized by Agaricia humilis (Scleractinian coral) larvae: Biological Bulletin, v. 181, p. 104-122.

National Oceanic and Atmospheric Administration, National Centers for Coastal Ocean Science, 2012, Habitat digitizer extension (ArcGIS 10.0): Environmental Systems Research Institute, Inc., http://www.arcgis.com/home/item.html?id=aaa88d03d6cd499db77f663bdcb77173.

National Park Service, 2013, National Park protects coral reefs from destructive crown of thorns starfish: National Park Service News Release, December 16, 2013, 3 p., available at http://www.nps.gov/npsa/learn/news/upload/National-Park-Protects-Coral-Reefs-fromDestruction-Crown-of-Thorns-Starfish.pdf.

Raimondi, P.T., and Morse, A.N.C., 2000, The consequences of complex larval behavior in a coral: Ecology, v. 81, p. 3,193-3,211.

Richmond, B.M., 1995, Tutuila, American Samoa coastal resource inventory sitesReconnaissance shoreline geology: U.S. Geological Survey Open-File Report 95-512, 89 p.

Richmond, B.M., Buckley, M., Etienne, S., Chagué-Goff, C., Clark, K., Goff, J., DomineyHowes, D., and Strotz, L., 2011, Deposits, flow characteristics, and landscape change resulting from the September 2009 South Pacific tsunami in the Samoan islands: Earth-Science Reviews, v. 107, p. 38-51, doi:10.1016/j.earscirev.2011.03.008.

Rogers, C.S., 1990, Responses of coral reefs and reef organisms to sedimentation: Marine Ecology Progress Series, v. 62, p. 185-202.

Rohman, S.O., and Monaco, M.E., 2005, Mapping Southern Florida's shallow-water coral ecosystems - an implementation plan: National Oceanic and Atmospheric Administration Technical Memorandum NOS NOCCOS 19, available at http://www2.coastalscience.noaa. gov/publications/handler.aspx? resource=4QwqRLLqYwP/9XKAYHRhKijbgdDpOwhq19wgE $\mathrm{pbQVqo}=$.

U.S. Army Corps of Engineers Pacific Ocean Division, 1980, American Samoa coral reef inventory (ASCRI Project); Part A-Text: U.S. Army Corps of Engineers Pacific Ocean Division, $314 \mathrm{p}$.

U.S. Environmental Protection Agency, 2007, Climate change and interacting stressorsImplications for coral reef management in American Samoa: Global Change Research 
Program, National Center for Environmental Assessment, EPA/600/R-07/069, 72 p., available at http://cfpub.epa.gov/ncea/risk/recordisplay.cfm?deid=173312\&CFID $=54893476 \&$ CFTOKEN=58709152.

Whaylen, L., and Fenner, D., 2006, Report of 2005 American Samoa coral reef monitoring program (ASCRMP), expanded edition: Department of Marine and Wildlife Resources Biological Report Series No. 2006-1, 64 p.

Whitall, D., and Holst, S., 2015, Pollution in surface sediments in Faga'alu Bay, Tutuila, American Samoa: National Oceanic and Atmospheric Administration Technical Memorandum NOS/NCCOS 201, 54 p., available at http://www2.coastalscience.noaa.gov/publications/ handler.aspx? resource $=\mathrm{dHjXfxOtmskClXQqUFqxzdS8FqdQc1AoEqtRBWCnPE4=}$ 


\section{Appendix-Detailed Classification Scheme}

The classification scheme described here is used by the U.S. Geological Survey for benthic habitat mapping of the U.S. Coral Reef Task Force Watershed Partnership Initiative Faga'alu Bay priority study area, Tutuila, American Samoa. Each of the habitats and zones is described in detail with some example photos. Many of the descriptions are from the National Oceanic and Atmospheric Administration classification scheme for the main eight Hawaiian Islands (Coyne and others, 2003), and its subsequent revision (Analytical Laboratories of Hawaii, 2004).

\section{Habitats}

Major Structure_Unconsolidated Sediment

- $\quad M u d$-Fine sediment commonly associated with stream discharge and buildup of organic material in areas sheltered from high-energy waves and currents (for example, harbors and fishponds).

- Sand-Coarse sediment typically found in areas exposed to currents or high wave energy (reef-derived) or on beaches (land-derived or reef-derived).

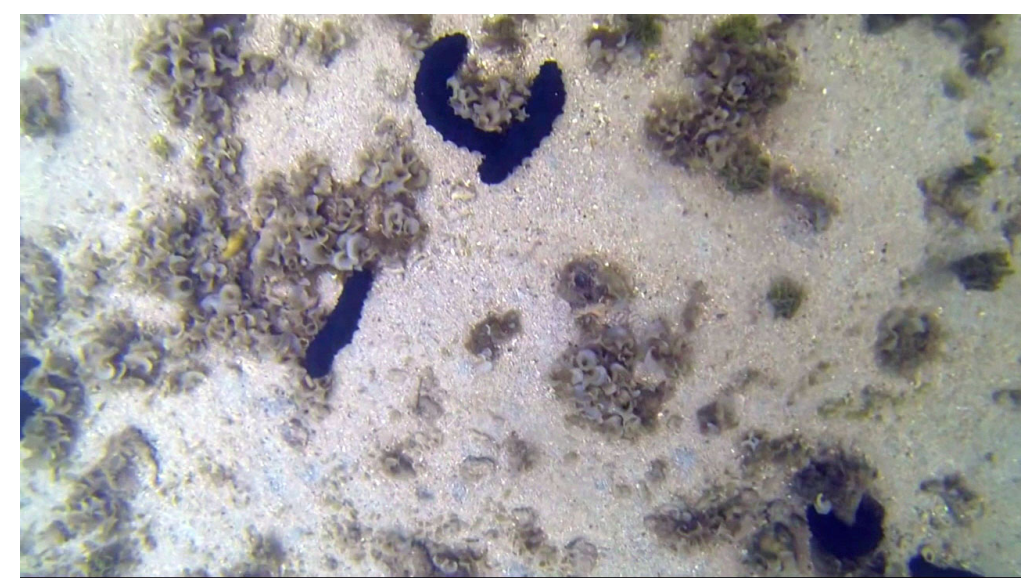

Figure A-1. Photograph showing an example of sand with 10-<50 percent macroalgae (Faga'alu Bay).

\section{Major Structure-Reef and Hardbottom}

- Aggregate reef-Formations with high relief and complexity, which form an extensive reef structure without sand channels (as found in spur-and-groove formations). Note that aggregate reef refers to the underlying hard structure and implies nothing about the nature of the biological cover, nor whether it is living or dead. 


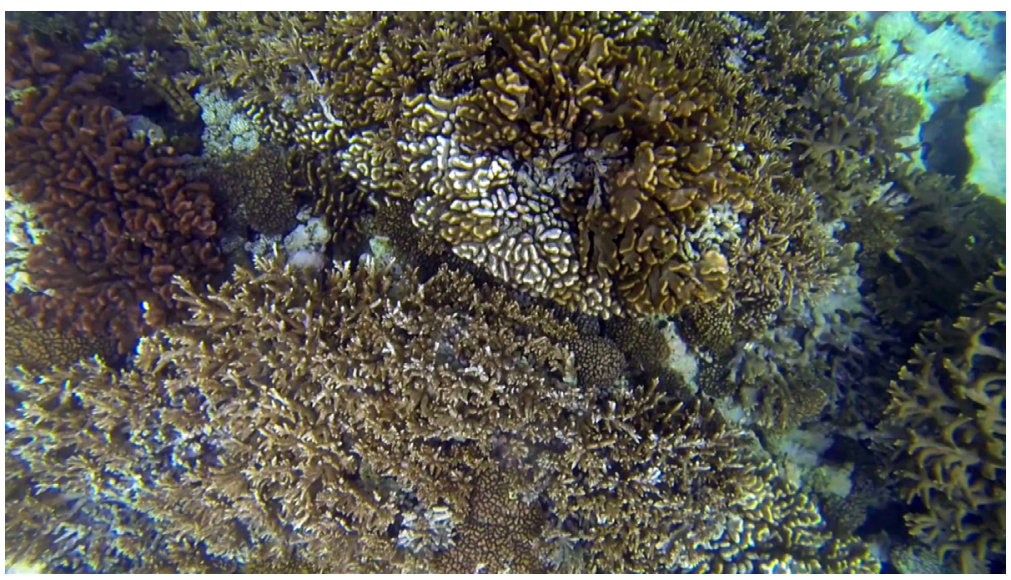

Figure A-2. Photograph showing an example of aggregate reef with 50-<90 percent coral (Faga'alu Bay).

- Spur-and-groove-Elongate, alternating sand and coral formations that are oriented perpendicular to the shore or bank/shelf escarpment. The coral formations (spurs) of this feature typically have a high vertical relief relative to the pavement with sand channels class, and are separated from each other by $1-5 \mathrm{~m}$ of sand or bare pavement (grooves). There are no spur-and-groove formations found in this map area.

- Individual patch reef - Coral formations, larger than or equal to the minimum mapping unit (MMU) (100 $\mathrm{m}^{2}$ in this study), that are isolated from other coral reef formations by sand, seagrass, or other habitats and have no organized structural axis relative to the contours of the shore or shelf edge.

- Aggregated patch reef - Clustered coral formations, smaller than the MMU $\left(100 \mathrm{~m}^{2}\right.$ in this study) or too close together to be mapped separately, that are isolated from other coral reef formations by sand, seagrass, or other habitats and that have no organized structural axis relative to the contours of the shore or shelf edge.

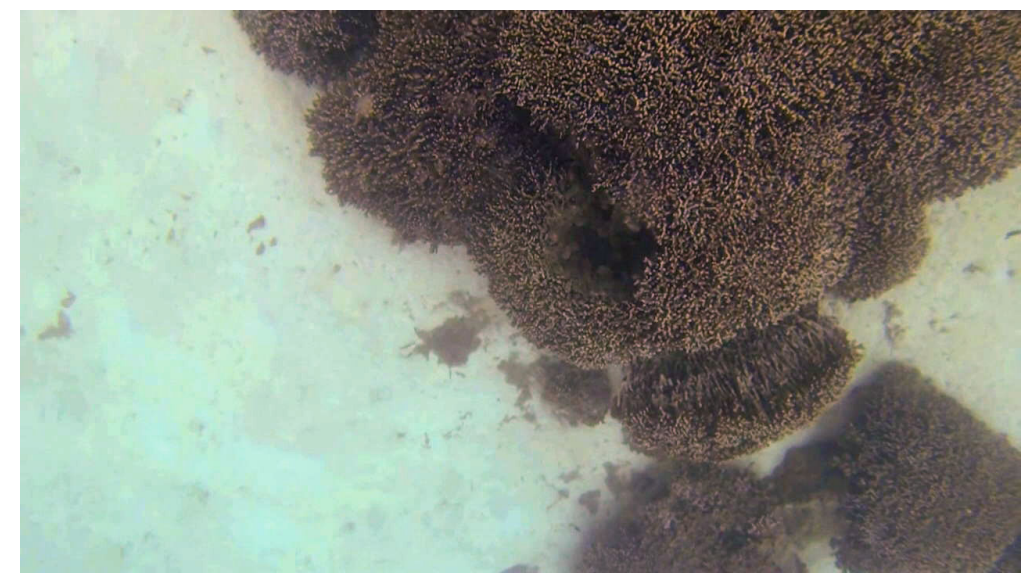

Figure A-3. Photograph showing an example of aggregated patch reef covered with $50-<90$ percent coral (Faga'alu Bay). These patch reefs are smaller than minimum mapping unit and, therefore, could not be called individual patch reefs. 
- Scattered coral/rock-Pavement or sand with $>10$ percent small corals or rocks scattered on the surface. Generally found in a transition zone between pavement or sand and higher relief reef structures.

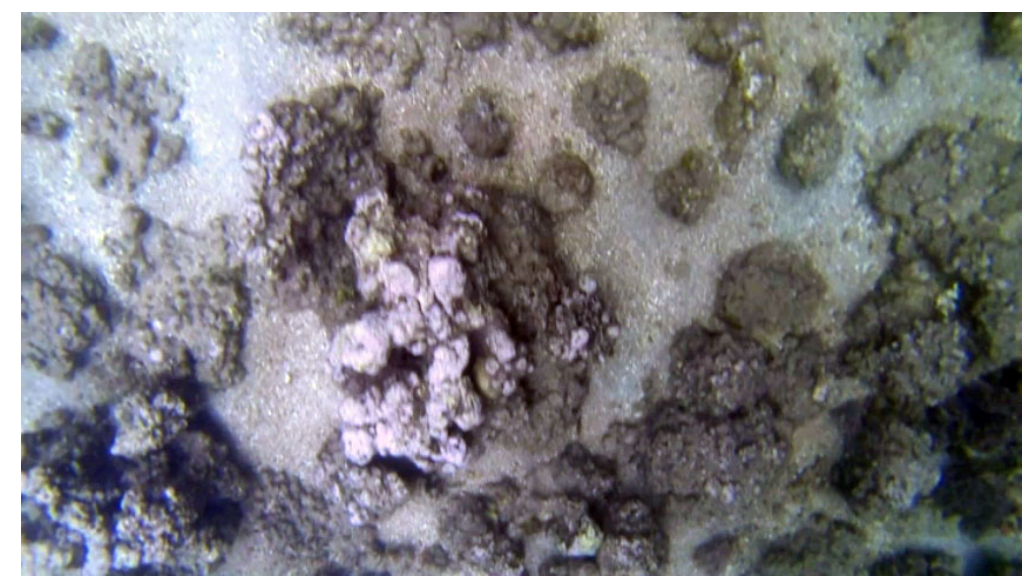

Figure A-4. Photograph showing an example of scattered coral/rock with 10-<50 percent coralline algae (Faga'alu Bay).

- Pavement-Carbonate or volcanic substrate with $<10$ percent loose rocks or boulders scattered on the surface. Volcanic substrate may be smooth or irregular, depending on the original lava flow and subsequent erosion patterns.

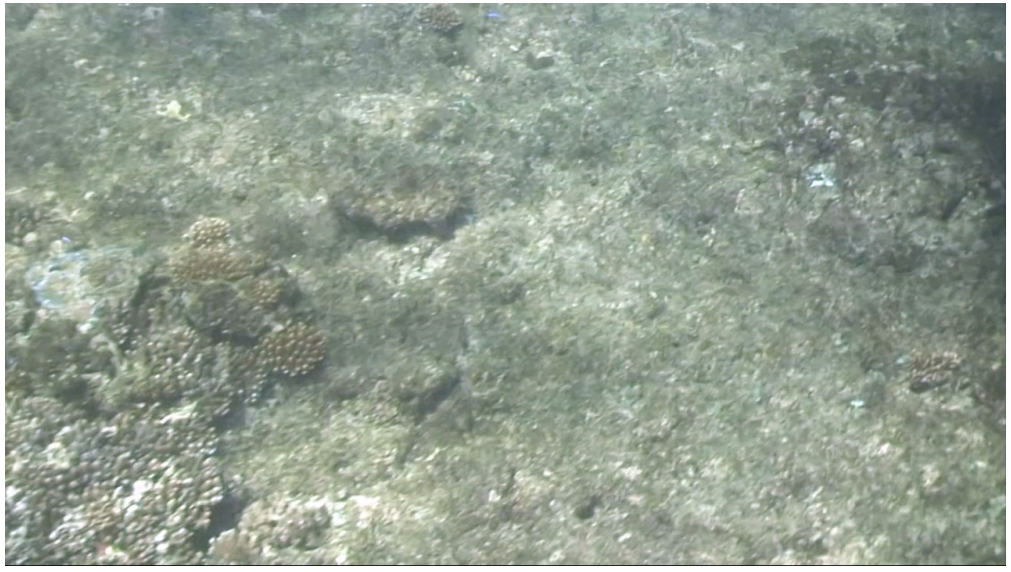

Figure A-5. Photograph showing an example of volcanic pavement with $50-<90$ percent turf algae (Faga'alu Bay).

- Pavement with sand channels - Carbonate or volcanic substrate alternating with sand channels that are oriented perpendicular to the shore or bank/shelf escarpment. The sand channels have low vertical relief relative to spur-and-groove formations.

- Rocks/boulders - Carbonate or volcanic substrate with $>50$ percent rocks and (or) boulders scattered on the surface. The underlying substrate may be smooth or irregular. 


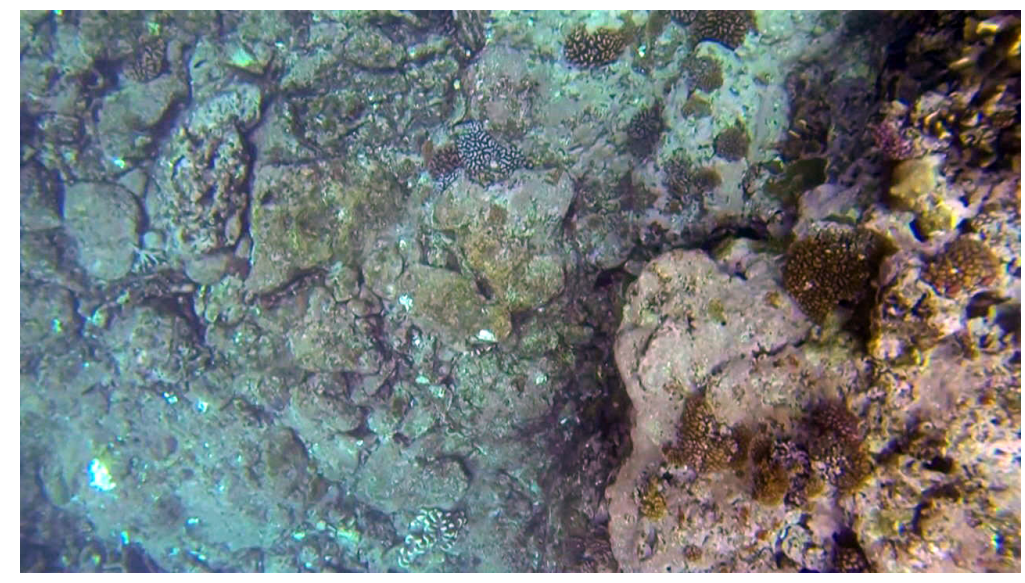

Figure A-6. Photograph showing an example of substrate with $>50$ percent rocks/boulders, with $10-<50$ percent coral cover (Faga'alu Bay).

- Reef rubble-Dead, unstable coral rubble, commonly covered with coralline algae or filamentous or other macroalgae.

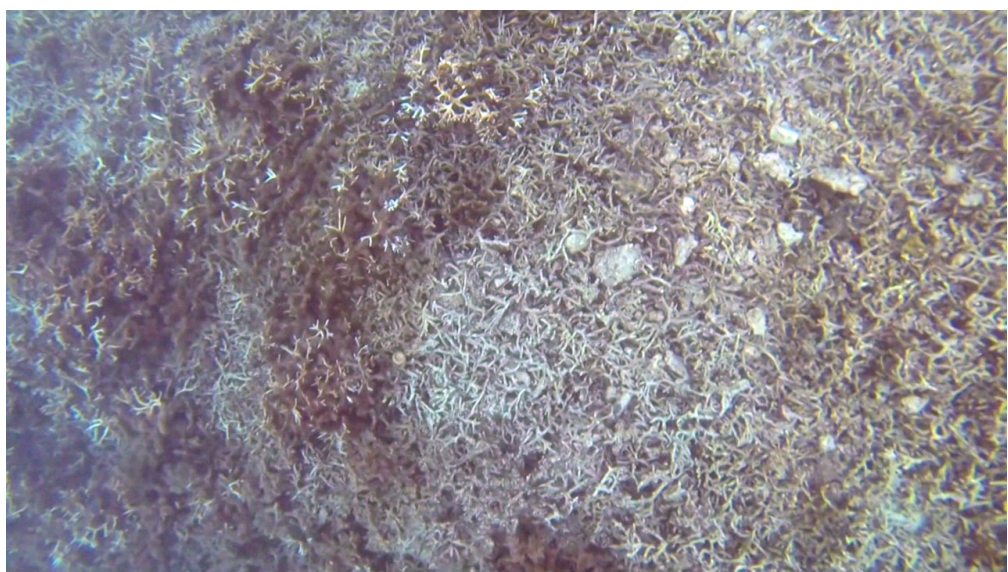

Figure A-7. Photograph showing an example of reef rubble with $10-<50$ percent macroalgae (Faga'alu Bay).

\section{Major Structure-Other}

- Land-Area shoreward of the mean high water line, or landward edge of emergent vegetation, when present. Also may include offshore emergent features such as rock.

- Artificial-Manmade habitats such as large piers, submerged parts of riprap jetties, and shoreline areas created from dredge spoil.

\section{Zones}

- Land-Area shoreward of the mean high water line, or landward edge of emergent vegetation, when present. Also may include offshore emergent features such as rock. 
- Shoreline/intertidal -Area between the mean high water line (or landward edge of emergent vegetation) and lowest spring tide level. Typical habitats include mangrove and other emergent vegetation, sand, mud, and uncolonized rock.

- Wall-Area with near-vertical slope along channels, from shelf to shelf escarpment, or between different inner-shelf platforms. This zone typically is narrow and may not be visible in remotely sensed imagery, but is included because it is recognized as a biologically important feature. Typical habitats include coral, algae, and uncolonized rock.

- Lagoon-Shallow area between the shoreline/intertidal zone and the back reef zone of a barrier reef system. If no reef crest is present, there is no lagoon zone. Typical habitats include individual patch reefs, sand, seagrass, algae, and pavement.

- Back reef (with lagoon) - Area between the seaward edge of a lagoon floor and the landward edge of a reef crest. This zone is present only when reef crest and lagoon also are present. Typical habitats include sand, coral rubble, seagrass, algae, and patch reefs.

- Reefflat (without lagoon) - Shallow, semi-exposed area between the shoreline/intertidal zone and the reef crest of a fringing reef system. This zone is protected from the highenergy waves commonly experienced on the reef crest and fore reef. The reef flat is not present if there is a lagoon. Typical habitats include sand, reef rubble, pavement, algae, mud, and patch reefs.

- Reef crest -Flattened, emergent (especially during low tides) or nearly emergent segment of a reef, generally where the waves break. This zone is between the back reef and fore reef zones of a barrier reef system, and between the reef flat and fore reef of a fringing system. Typical habitats include reef rubble, patch reefs, and pavement.

- Fore reef-Area from the seaward edge of the reef crest that slopes into deeper water to the landward edge of the bank/shelf platform. Fore reef is also defined as features not forming an emergent reef crest but still having a seaward-facing slope that is markedly greater than the slope of the bank/shelf. Typical habitats include aggregate coral reef and spur-and-groove.

- Bank/shelf -A deep-water platform extending offshore from the seaward edge of the fore reef to the beginning of the escarpment where the insular shelf drops off into deep, oceanic water. If no reef crest is present, the bank/shelf is the flattened platform between the shoreline/intertidal zone and deeper ocean offshore. Typical habitats include sand, patch reefs, algae, colonized and uncolonized pavement with and without sand channels, and other coral habitats.

- Bank/shelf escarpment-The edge of the bank/shelf where depth increases sharply into deep, oceanic water. This zone typically begins in water depths of about $20-30 \mathrm{~m}$, near the depth limit of features visible in aerial images, with habitats including sand, aggregate reef, and spur-and-groove. However, around Tutuila this zone begins in water depths of about $100 \mathrm{~m}$, and includes the transition from the shelf to deep oceanic waters.

- Channel-Naturally occurring channels that commonly cut across several other zones. Locally known as "ava." Typical habitats include sand, mud, and uncolonized pavement.

- Dredged-Area in which natural geomorphology is disrupted by excavation or dredging (for example, harbors and manmade channels). Typical habitats include reef rubble, sand, and mud. Around Tutuila, patches of coral may be found in the sand-covered dredged areas. 
ISSN2331-1258 (online)

http://dx.doi.org/10.3133/of

20161077 